Illinois State University

ISU ReD: Research and eData

Theses and Dissertations

7-3-2014

\title{
Police Officer Job Satisfaction and Officer-Sergeant Educational Levels: A Relational Demography Perspective
}

Sung Uook Lee

Illinois State University, slee3@ilstu.edu

Follow this and additional works at: https://ir.library.illinoisstate.edu/etd

Part of the Criminology Commons, and the Criminology and Criminal Justice Commons

\section{Recommended Citation}

Lee, Sung Uook, "Police Officer Job Satisfaction and Officer-Sergeant Educational Levels: A Relational Demography Perspective" (2014). Theses and Dissertations. 237.

https://ir.library.illinoisstate.edu/etd/237

This Thesis is brought to you for free and open access by ISU ReD: Research and eData. It has been accepted for inclusion in Theses and Dissertations by an authorized administrator of ISU ReD: Research and eData. For more information, please contact ISUReD@ilstu.edu. 


\title{
POLICE OFFICER JOB SATISFACTION AND OFFICER-SERGEANT EDUCATIONAL LEVELS: A RELATIONAL DEMOGRAPHY PERSPECTIVE
}

\author{
Sung Uook Lee
}

83 Pages

December 2014

One immediate component of officers' work environment that has the potential to have a significant influence on officers' job satisfaction is front-line supervision.

Frontline supervisors have been found to impact officers' attitudes in general (Engel, 2000). Additionally, Van Maanen (1983) found that supervisors may impact officers by rewards or punishment. Although it has been researched that supervisors impact officers' attitudes or behavior (Terrill, 2001; Davis \& Mateu-Gelabert, 1999), Walker (2007) concluded that there is still little research on the impact of supervisors on officer job satisfaction. As aforementioned in this thesis, police officers' job satisfaction has largely been studied in terms of basic demographics, such as educational differences Although basic demographic characteristics are very important part of officers' job satisfaction, it neglects the broader environment where officers' work, especially with respect to frontline supervision. Thus, this thesis focuses on including supervision into the study of officer education and job satisfaction. 
POLICE OFFICER JOB SATISFACTION AND OFFICER-SERGEANT

EDUCATIONAL LEVELS: A RELATIONAL DEMOGRAPHY

PERSPECTIVE

SUNG UOOK LEE

A Thesis Submitted in Partial

Fulfillment of the Requirements

for the Degree of

MASTER OF SCIENCE

Department of Criminal Justice Sciences

ILLINOIS STATE UNIVERSITY

2014 
Copyright 2014 Sung Uook Lee 
POLICE OFFICER JOB SATISFACTION AND OFFICER-SERGEANT

EDUCATIONAL LEVELS: A RELATIONAL DEMOGRAPHY

PERSPECTIVE

SUNG UOOK LEE

COMMITTEE MEMBERS:

Jason R. Ingram, Chair

Michael C. Gizzi

Philip Mulvey 


\section{CONTENTS}

CONTENTS

TABLES $\quad$ iii

\section{CHAPTER}

I. INTRODUCTION 1

Statement of the Problem 1

Purpose of Study 3

Importance of Study 4

Overview of Thesis $\quad 5$

$\begin{array}{lll}\text { II. } & \text { LITERATURE REVIEW } & 7\end{array}$

Defining Job Satisfaction $\quad 7$

Locke on Job Satisfaction $\quad 7$

Importance of Job Satisfaction on Policing 9

$\begin{array}{ll}\text { Traditional Sources of Job Satisfaction } & 10\end{array}$

$\begin{array}{ll}\text { Basic Demographic Characteristics } & 10\end{array}$

Race/Gender 11

Age/Tenure 13

Rank 14

Educational Level 15

$\begin{array}{ll}\text { Work Environment } & 17\end{array}$

Job Autonomy 19

Job Stress 20

Job Feedback $\quad 21$

Job Variety 22

Frontline Supervision \& Officer Job Satisfaction 22

Role of Frontline Supervisors $\quad 23$

Review of Research in Other Discipline 24

Officers' Perception of Supervisors and Job Satisfaction 25

Influence of Frontline Supervisors on Officers' Attitude 27 
Sergeants' Education and its Impact on

Subordinate Officers' Behavior

Limitations of Prior Research

III. THEORETICAL FRAMEWORK 32

Overall Job Satisfaction and Edwin Locke $\quad 32$

What is Relational Demography? 33

How it May Apply to Current Thesis 35

$\begin{array}{ll}\text { IV. METHODOLOGY } & 40\end{array}$

Data Source-Secondary Data 40

Description of Survey Methodology 42

Sample $\quad 42$

Measures $\quad 44$

Dependent Variable: Job Satisfaction $\quad 45$

Primary Independent Variable: Educational Level $\quad 47$

Independent Variable: Basic Demographics 48

Control Variables $\quad 48$

$\begin{array}{lr}\text { Analysis } & 50\end{array}$

V. RESULTS 52

Univariate Analysis $\quad 52$

Bivariate Analysis $\quad 56$

Control Variables $\quad 58$

Multivariate Analysis $\quad 61$

$\begin{array}{lll}\text { VI. CONCLUSION } & 66\end{array}$

$\begin{array}{ll}\text { Findings } & 67\end{array}$

Limitations $\quad 69$

$\begin{array}{ll}\text { Practical Implications } & 70\end{array}$

$\begin{array}{ll}\text { Future Research } & 72\end{array}$

$\begin{array}{ll}\text { REFERENCE } & 73\end{array}$

$\begin{array}{ll}\text { APPENDIX: Tables } & 78\end{array}$ 


\section{TABLES}

Table

Page

1. Description of Study Variables 44

2. Description of Study Variables 55

3. Correlation of Educational Level Variables and Job Satisfaction 57

4. ANOVA Testing for Three Educational Cases 58

5. Race and Gender T-test of Officers and Sergeants 59

6. Correlation of Control Variables and Job Satisfaction 60

7. ANOVA of Department Variables and Job Satisfaction 60

8. Model 1 Regression 63

9. Model 2 Regression 65 


\section{CHAPTER I}

\section{INTRODUCTION}

\section{Statement of the Problem}

Job satisfaction continues to be one of the most studied employee attitudes in organizations. Research has tried to determine specific factors that might explain why some employees are satisfied with their work while others might be dissatisfied. One occupation where job satisfaction has received considerable attention is policing, due to its distinct job characteristics. For the past decades, researchers have examined police officer job satisfaction mainly in relation to demographic characteristics of officers, such as gender differences (Hassell, Archbold, \& Stichman, 2011; Krimmel \& Gormley, 2003); race (Buzawa, 1981); education (Dantzker, 1992); and other basic demographic characteristics (Seifert, \& Umbach, 2008; Ghafoor, 2012; Jo \& Hoover, 2011; Ercikti, Vito, Walsh, \& Higgins, 2011; Carlan, 2007). Although the focus of research on basic demographic characteristics has added knowledge to the field of criminal justice, it has not fully explained specific relationships among these demographics in determining police officers' job satisfaction.

The effect of education on officers' job satisfaction is one such relationship that has failed to come to a univocal conclusion (Ercikti et al., 2011; Bilgic, 1998; Lofkowitz, 1974; Ozel et al., 2009). For example, Lofkowitz (1974) identified that level of education was significantly associated to job satisfaction, but in an unanticipated direction: officers with master's degrees tended to exhibit the lowest levels of positive attitudes toward their 
jobs. On the other hand, Dantzker (1992) determined that education was associated positively with officers' job satisfaction. Also, Ercikti et al. (2011) suggested there was not a significant correlation between educational level and job satisfaction. Finally, Bilgic (1998) suggested that over educated personnel experience less job satisfaction. One potential reason for these mixed results may be due to the focus of prior research on the individual level nature of this relationship without taking into consideration the broader work environment in which officers work. For example, Zhao et al. (1999) has pointed out that there has been very limited research on the relationship between the work environment and officers' satisfaction levels.

One immediate component of officers' work environment that has the potential to have a significant influence on officers' job satisfaction is frontline supervision. Frontline supervisors have been found to impact officers' attitudes in general (Engel, 2000). Additionally, Van Maanen (1983) found that supervisors may impact officers by rewards or punishment. Although it has been researched that supervisors impact officers' attitudes or behavior (Terrill, 2001; Davis \& Mateu-Gelabert, 1999), Walker (2007) concluded that there is still little research on the impact of supervisors on officer job satisfaction. Police officers' job satisfaction has largely been studied in terms of basic demographics, such as educational differences. While basic demographic characteristics are very important part of officers' job satisfaction, it neglects the broader environment where officers' work, especially with respect to frontline supervision. Thus, this thesis focuses on including supervision into the study of officer education and job satisfaction. 


\section{Purpose of Study}

The goal of this thesis is to add to the limited knowledge of police officer job satisfaction in regards to educational level differences among supervisors and officers. For this reason, this thesis attempts to answer the following questions:

1. Does officers' educational level impact their job satisfaction?

2. Does sergeants' education level impact their subordinate officers' job satisfaction?

3. Does the difference between officers' and sergeants' educational level impact officers' job satisfaction?

To answer these questions, relational demography is utilized as the theoretical framework. The theory of relational demography suggests that differences between demographic characteristics of individuals within a group affect individual's attitudes and behaviors, such as organizational commitment and turnover (Riordan, 2000). This framework may also be applied to police officers' job satisfaction. Thus, in order to test the framework the current study aims to analyze 601 patrol officers and 82 sergeants from survey data collected and submitted to the National Institute of Justice by Terrill, Paoline and Ingram (2011), Assessing Police Use of Force Policy \& Outcomes project. Specifically, this study looks at three agencies out of the survey data from the project: Albuquerque, New Mexico (APD); Knoxville, Tennessee (KPD); and Fort Wayne, Indiana (FWPD). Through three statistical steps: 1) univariate analysis, 2) bivariate analysis, and 3) regression analysis, the current study's goal is to examine the impact of educational level difference of patrol officer and sergeant on job satisfaction. 


\section{Importance of Study}

This focuses on examining educational level differences between supervisors and officers. This particular area of inquiry is important for a number of reasons. First, prior research regarding the major determinants of job satisfaction, such as individual demographic differences, is inconsistent (Ercikti, 2011). Also, prior research focuses mainly on the work environment whereas the current study attempts to focus on integrating individual characteristics with the work environment through the use of relational demography. For example, prior research emphasizes the influence of several variables on officer job satisfaction. These include different views or ideology, the discrepancy of expectation and the reality of the job, perceived danger, promotion, and tenure of the job, organizational mistrust and lack of support. Each of these may be a contributor to work related stress which can lead to job dissatisfaction. Thus, the current study is essential to evaluate the unique concept of relational demography on officers' job satisfaction. As shown, previous studies focused on simple demographic characteristics. These characteristics could not explain in-depth dimension of police officers' job satisfaction. To examine police officer job satisfaction closely, this study is essential.

This research also may be a great addition of knowledge to administrators in police agencies. First, it may help the administrators to figure out the right combination of supervisors and subordinate officers that may lead to productive outcomes. Second, it may help the administrators to organize the agencies' organizational structure so that it will lead to the most beneficial outcome with the least amount of resources available. Negative outcome of police officer job satisfaction may lead to waste of limited resources available by police agencies. For example, agencies have to use limited resources to 
recruit, train, and replace police officers. This is due to job dissatisfaction which leads to high turnover/burnout rate of police officers. Also, satisfied officers may perform efficiently which may lead to hiring fewer officers. Finally, for the sake of the public safety and to reduce police officer turnover rate, this study is crucial to add to the limited body of knowledge currently available.

\section{Overview of Thesis}

The next chapter reviews the literature on police officer job satisfaction. The literature review assesses the general definition of police job satisfaction and then considers the possible sources of officer job dissatisfaction. Next, it includes recent research findings that give an overview of how recent studies were conducted and what their conclusions were. For the background of this thesis, the literature review includes sections of race, age/rank, and gender differences in basic demographics of officer job satisfaction. Most importantly, the next section deals with prior research related to educational level differences and officer attitudes relating to officer job satisfaction. Following the literature review section will be the theoretical framework, which aims to explain what relational demography is and how it applies to the current thesis. Next, the methodology chapter will deal with explaining how the current thesis will be examined. This section explains how the sample was obtained and where the sample came from, which is Assessing Police Use of Force Policy \& Outcomes project. The section also describes the variables, how they are measured, and the analytical framework of the thesis. Next section includes overview of results which explains the outcome of the statistical analysis. Finally, the last section provides conclusion of the thesis which includes application of the study, and conclusion of the study. 


\section{CHAPTER II}

\section{LITERATURE REVIEW}

\section{Defining Job Satisfaction}

There are various definitions of job satisfaction. The current thesis aims to include definitions widely used in the policing and private sector literature. The main focus of this thesis is on global job satisfaction. Global job satisfaction deals more with emotional experience of job satisfaction, or overall satisfaction. Since job satisfaction is an intangible concept, conceptualizing job satisfaction is vital. Locke (1976) argues that due to the fact that satisfaction is an emotional response to one's job, this concept can only be explored by self-diagnosis of the content. For this reason he suggests that "job satisfaction may be defined as a pleasurable or positive emotional state resulting from the appraisal of one's job or job experiences" (Lock, 1976, p. 1300). For example, Locke claimed that job satisfaction is due to the difference between the employee's expectation of the job and the reality of the job (Locke, 1976). On this premise, job satisfaction of police officer is vital to explore due to the major differences in police officers' expectation of the job when coming in and the reality of the job.

\section{Locke on Job satisfaction}

Locke (1976) presents a very specific and thorough assessment and explanation of job satisfaction. He starts by explaining the historical trends of job satisfaction by each 
school. First, The Physical-Economic School emphasizes more on physical working conditions and pay. Second, The Social (or Human Relations) School focuses on the role of good supervision, cohesive work groups and friendly employee-management relationship. Third, Work Itself (or Growth) School focuses on satisfaction through development of skill, efficacy, and responsibility by mentally challenging work (Locke, 1976).

Locke (1976) also emphasizes four components of job satisfaction that include: expectancies, needs, values, and need-value conflicts. He uses these four factors claiming that individuals' reaction depends on the interaction between the person and the person's surrounding environment (Locke, 1976). First, expectancies relates to job satisfaction by whether or not a person can attain an expected outcome out of his or her job. He suggests that expectancies can work both directions, meaning "whether the surprise is pleasant or unpleasant depends upon whether the deviation from expectancy is in a direction one values or a direction one disvalues" (Locke, 1976, p. 1303). Second, needs is the fulfillment of individuals' needs. Locke (1976) asserts that there are two categories of needs: 1) physical needs and 2) psychological needs. Physical needs are the requirement of a healthy, properly functioning body such as food, water, rest. Psychological needs are the requirements of a healthy, properly functioning consciousness such as sensory stimulation, self-esteem, and pleasure. Third, "value is what a person consciously or subconsciously desires, wants, or seeks to attain" (Locke, 1976, p. 1304). The author claims that needs are innate human basic needs and values are acquired by what they want in life (Locke, 1976). The last category is need-value conflicts. As Locke explains, "since it is the existence of needs which gives rise to the requirement of action, and, 
therefore, to the requirement of pursuing values, it would be self-contradictory to claim that any value was a good as another or that all values will yield the same degree of pleasure once attained" (Locke, 1976, p. 1306). To conclude what job satisfaction is, Locke states that, "job satisfaction results from the perception that one's job fulfills or allows the fulfillment of one's important job values, providing and to the degree that those values are congruent with one's needs" (Locke, 1976, p. 1307).

\section{Importance of Job Satisfaction on Policing}

More reasoning of the importance of research on police job satisfaction exists. First, negative attitudes toward work can negatively affect officer job performance. This poor performance can impact police and community relationships by degrading the public attitudes towards the police (Buzawa, Austin , \& Bannon, 1994). Police officer job satisfaction is directly related to citizens' trust, police legitimacy, and most importantly to up hold the law. When officers who are employed by the state to up hold the law are not acting within the legitimate boundaries of his/her job requirement because he/she is unhappy with his/her job, adverse relations with the public can result. Additionally, having police officers' with high job satisfaction may lessen the turnover rate and job stress (Zhao, Thurman, \& He, 1999). Job turnover rate is important because of financial reasons. Loo (2004) suggested that increased recruitment and training expenses for new police resulted from high employee turnover due to work stress. This added financial burden negatively affected the already limited budgets of police agencies.

Ercikti, Vito, Walsh, \& Higgins (2011) emphasized the importance of investigating police job satisfaction. They claimed that negative attitudes toward work 
can adversely affect job performance in both the quantity and quality of services provided; implying that if an officer has a negative assumption towards his or her job, they will express their stress intentionally or unintentionally towards the citizens that they encounter (Ercikti, Vito, Walsh, \& Higgins, 2011). This encounter will provoke citizen's siege mentality of us versus them; leading to police officer's job dissatisfaction and consequently also leading to more negative attitudes by officers. Ercikti et al. (2011) emphasizes that because of negative outcomes of police job dissatisfaction, it is important to satisfy officers because job satisfaction promotes lower levels of job stress, and burnouts which may lead to better performance of police officers. As these few reasons show, it is critical to explore possible explanations for police officers' job satisfaction.

\section{Traditional Sources of Job Satisfaction}

More studies have found various factors that emphasize police officer job satisfaction. A variety of factors that influence officers' job satisfaction exists. Although prior research has focused on various factors that may influence officers' job satisfaction, this thesis mainly focuses on basic demographics such as: race, gender, age/tenure, educational level, work environment and supervisor impact which are presented in the following section.

\section{Basic Demographic Characteristics}

As presented above, it is very important to conduct in-depth research about police officer job satisfaction because of its contradicting findings, major impact on officers, and to add to the knowledge of police officer job satisfaction. In order to better understand the goals of this thesis, we first need to explore the basic demographic 
differences and its relation to job satisfaction. Looking into Buzawa's (1984) research, four basic demographic variables for police officer job satisfaction have been studied: race, gender, age/tenure, and educational level.

\section{Race/Gender}

Race and gender may be the most basic factors of job satisfaction. Before exploring any other factors, we must explore tokenism: minority in a dominant group. According to Stroshine and Brandi (2011), "tokens are expected to experience a variety of hardships in the workplace, such as feelings of heightened visibility, isolation and limited opportunities for advancement" (p. 1). Within tokenism theory, there are three factors that influence the minority members in a dominant group: visibility, polarization, and assimilation. First, visibility is when token members stand out compared to dominant group members because they are different (Stroshine \& Brandi, 2011). For this reason, Stroshine and Brandi (2011) states that the tokens feel added pressure to perform better than the dominant group because they constantly feel they are being watched. Second, polarization occurs when the differences between the token and the dominant group are inflated and the similarities are minimized. Lastly, assimilation is the result of dominant group members not being sure how to treat the minority tokens. This uncertainty results in treating tokens in stereotypical ways (Stroshine \& Brandi, 2011).

Research has shown that tokenism exists in policing. For example, Dowler (2005) found that black officers were more likely to perceive criticism from peers and female officers were more likely to believe that they were criticized more than peers (Dowler, 2005). Also, Stroshine and Brandi (2011) concluded that white females, minority males, 
and minority females all felt significantly more isolation and polarization compared to white male officers. Additionally, the researchers found that minority officers perceived less opportunity for preferred assignments compared to the white males, and minority female officers reported the highest levels of tokenism. The authors concluded that race was a more important factor than gender in determining the levels of tokenism (Stroshine \& Brandi, 2011).

More examples of race and gender inequality exist that result in officers job dissatisfaction. Hassell and Brandi (2009) studied workplace experiences of officers with nine categories. The nine category being lack of support/ opportunity, negative physical abilities, negative uniform/equipment, victim of theft, ridicule, sexually offensive behaviors, perceptions of bias, and perceptions of vulgar language. The result of this thesis also provided evidence that race and gender played a significant role in terms of officers' job satisfaction. Black officers reported significantly more negative workplace experiences compared to white male officers; for example, lack of opportunity, other officers underestimating their physical abilities, being a victim of theft, perceptions of bias, and perceptions of vulgar language (Hassell \& Brandi, 2009). Also, white female officers reported more negative workplace experiences compared to white male officers, such as: negative physical abilities, perception of sexually offensive behaviors, perception of bias, and perception of vulgar language (Hassell \& Brandi, 2009). Black female officers reported negative workplace experience on all fields except uniform and equipment and Latina officers also reported negative work place experiences (Hassell \& Brandi, 2009). Johnson (2012) also found that black officers were generally more satisfied with their job. 
More determinants or stressors of job dissatisfaction exist. Haar and Morash (1999) claimed that female and minority officers have different attitudes and views on police work and have different experiences in policing. They concluded that domination by white officers in policing resulted in token officers feeling excluded from mainstream policing as well as uncomfortable in their work (Haarr \& Morash, 1999). Toch (2002) illustrated both majority and minority claims of discrimination. To explain white officers claimed that black officers received special treatment or impunity because of politics within the department; on the other hand black officers claimed that they felt discriminated against and felt their opportunity of career advancement was limited due to discrimination (Toch, 2002). Hunt and McCadden (1985) concluded that when coded into white and black officers, black officers felt significantly more dissatisfied compared to white officers. Surprisingly, when considering the policing officers' gender, results only showed a mediocre and statistically non-significant result with job satisfaction. Race is a complicated predictor in police office job satisfaction since both whites and minorities claim to be the victim of racial discrimination. Not only is race a predictor of job satisfaction, age/tenure/rank also has influence on officers' job satisfaction.

\section{Age/Tenure}

Age/Tenure appears to be another important factor for police officer job satisfaction. Previous research has shown that cynicism build as the police officers' tenure increases. Johnson (2012) found that the longer the officers' tenure, the lower the job satisfaction levels. Carlan (2007) found that officers with less than one year of police experience were most satisfied out of all. Officers with 53 years of age or more were second most satisfied and officers between the ages of 37 to 52 were the least satisfied 
(Carlan, 2007). This could be explained by officers burning out throughout their career in the ages of 37 to 52 and officers with less than a year of experience still having the image of policing as exciting and adventurous, which leaves rookie officers with the most satisfaction. For the eldest group, ages 53 and up, higher job satisfaction might be explained because of their seniority or impending, which makes them the second satisfied group of all. Similar to these findings, Hunt and McCadden (1985) found that as officers were younger, they portrayed greater levels of dissatisfaction and greater satisfaction as officers aged. Ironically, even though Hunt and McCadden's study found that younger officers were more dissatisfied with their job, tenure was also associated with higher levels of dissatisfaction. That is, as officers had more experience, they portrayed lower levels of satisfaction significantly. Contradicting prior examples, Miller, Mire, and Kim (2009) found that rank and tenure had statistical significance on job satisfaction. Miller et al. concluded that age and years of experience (tenure) actually had a significantly negative correlation on job satisfaction. That is, as officers aged or had spent more time on the force, they diminished their job satisfaction. Similar to age/tenure but with a slight difference, rank variable was also a very important indicator of officers' job satisfaction.

\section{Rank}

Similar to the findings of age/tenure, Oshagbemio (1997) studied job satisfaction of academics in relation to their age/ranks. The study found that academics on higher ranks were generally more satisfied with their jobs compared to the lower ranks. Most importantly, academics that were less than 35 years old had the least satisfaction and those of 55 year and older had the most satisfaction (Oshagbemi, 1997). Hunt and McCadden (1985), with rank variable coded into command and non-commanding 
officers, indicated that non-commanding officers had significantly higher levels of job dissatisfaction and officers in commanding position had higher levels of job satisfaction. Contrary to Hunt and McCadden (1985), Miller, et al. (2009) asserted that rank was negatively correlated with job satisfaction for police officers. That is, as officers went up in rank, their perception of job satisfaction diminished.

\section{Educational level}

Educational level and police officers' job satisfaction seems to have an important relationship. Lofkowitz (1974) identified that level of education was significantly associated to job satisfaction, but in an unanticipated direction: officers with master's degrees tended to exhibit the lowest levels of positive attitudes toward their jobs (Lofkowitz, 1974). On the other hand, Dantzker (1992) determined that education was associated positively with officers' job satisfaction. An additional source of job satisfaction relates to the level of and the length of education. Fabra Florit and Vila Lladosa (2007) stated that highly educated people are thought to form more accurate expectations and to pursue their aspirations more efficiently than poorly educated people do. As a result, they are more likely to acquire additional education-enhanced benefits (Fabra Florit \& Vila Lladosa, 2007). In other words, if highly educated employees who know exactly what they want do not receive what they want, job dis-satisfaction will be certain to occur.

Similar results have been found by other scholars, who have studied the relation of educational level and job satisfaction. For example, Regoli (1976) found that college educated officers were more cynical than less educated officers. He suggested that better 
educated officers perceived themselves as more professionally qualified for the job but they were not allowed to have a great amount of autonomy due to regulations by the department (Regoli, 1976). Adding to this study, Trojanowicz and Nicholson (1976) also suggested that college educated officers preferred less regulation and control from their supervisors and wanted challenging jobs. To give officers more satisfaction, they concluded that the department should give them more challenging tasks that gets the officers excited, and that provide a higher level of communication in work, feedback, and participative decision making (Trojanowicz \& Nicholson, 1976). Dantzker (1992) found that there was a positive relationship between higher education and police officer job satisfaction; but, this relationship only existed with officer having less than five years of experience. The relationship was negative after five years of experience (Dantzker, 1992).

In a more recent study of Turkish police, Balci (2011), found that higher educational achievements may be related to higher job expectations. Simply, more educated people expect more from their jobs and when these expectations are not met, they will become dissatisfied with work. Summarizing from the studies presented above, educational level seems to heighten the expectation of the job, and if these expectations are not met, lower level of job satisfaction will follow. Balci (2011) suggests that persons who are more educated expect more for their accomplishment and autonomy at work and more chances of advancement; when these desires are not met, an officer will become dissatisfied. Contradicting prior research, Miller et al. (2009) claimed that level of education had a negative correlation with job satisfaction but it was not to the level where it was statistically significant. On the other hand, Hunt and McCadden (1985) concluded 
that although education level of police officers had positive correlation with job satisfaction, it did not have statistical significance. Unfortunately, it is not only these basic demographics that determine officers' job satisfaction/dissatisfaction. As previously listed, work environment also plays an immense role on police officers' job satisfaction.

\section{Work Environment}

Carlan (2007) concluded that basic demographic characteristics can only explain $3 \%$ of job satisfaction variance. Also, Carlan asserted that even though age and race emerge as significant predictors, the individual contributions were small (Carlan, 2007). For this reason, it is essential to look beyond basic demographics in order to explain job satisfaction more thoroughly. The most prominent alternative explanation of job satisfaction is the work environment. For example, Herzberg's Two Factor Theory of Motivation (1968) claims that employee's job satisfaction is determined mainly by his or her immediate work environment, meaning the managers should primarily focus on the environment of the work to increase employees' job satisfaction and motivation. Herzberg (1968) identified important sources of job satisfaction in terms of work environment: (1) importance of work itself; (2) responsibility one has while working; (3) recognition received from working. On the other hand, job dissatisfaction is due to strict policies, overemphasis on rules, in-adequate working conditions, and poor interpersonal relationships (Herzberg, 1968).

According to Herzberg (1959), many different factors combine to create job satisfaction and dissatisfaction among employees. Herzberg recognized these factors as motivators or hygiene factors listed below. Herzberg included motivators as: (1) 
achievement, (2) responsibilities, (3) the work itself, (4) recognition and (5) advancement and/or promotion. Herzberg determined hygiene factors as: (1) organizational policies, (2) supervision and leadership, (3) pay or salary, (4) work conditions, and (5) communication with supervisors and work partners (Hertzberg, Mausner, \& Snyderman, 1959). Due to this reasoning of categories of job satisfaction and dissatisfaction, Herzberg claimed that employees needed to reach an acceptable level of hygiene factors in order to feel neutral about their jobs. Thus, it is essential for the employers to set straight any hygiene factors in order to focus on improving on the motivational factors to increase job satisfaction which will lead to better job performance. Another paper that dealt with the importance of work environment was Hackman and Oldham (1976). This study developed five dimensions that were significantly correlated with job satisfaction and employees' motivation. The five dimensions were: skill variety (activities that challenge skills and abilities); task identity; task significance (how much the job affects other people's lives); responsibility (employee's autonomy over how they will perform); and knowledge of results (from feedback to the employee about the effectiveness of worker's efforts) (Hackman \& Oldham, 1976).

Work environment is a crucial factor in any work place, but above all, work environment in police organizations may be of importance due to their unique structure. Reviews provided below show the importance of work environment factors in relation to officer job satisfaction.

In 2007, a study conducted by Carlan suggested that, statistically, factors such as: pay, adventure/excitement in work, autonomy, social contribution, peer respect, enforcing law, and job security were each predictors of work environment related police job 
satisfaction (Carlan, 2007). A more recent study in 2011 provided comparable research results. This study concluded that the largest correlation occurs between feedback and autonomy of officers (Ercikti et al., 2011). That is, officers are most likely to have satisfaction when their supervisor gives feedback for the good and bad they have done in the job. Research has also shown that officers with more discretion (autonomy) and officers who received more positive feedback from supervisors explained more than $33 \%$ of the officer job satisfaction variance (Zhao, Thurman\& He, 1999). The authors also suggest that worker's perception of independence and feedback from the supervisor, in these case police officers, is critical in relation to work environment satisfaction. Such factors, which are work environmental factors, have vital influence on officers' job satisfaction. More work environmental factors are provided below that influences officers' job satisfaction.

\section{Job Autonomy}

According to Johnson (2012), job task characteristics have immensely greater impact on job satisfaction compared to worker demographic characteristics. Also, Hackman and Lawler (1971) states that there are three important characteristics that influence job tasks: Job variety, autonomy, and stress. Zhao et al. (1999) provided evidence that as job autonomy increases, officers' job satisfaction also increased. Miller, Mire, and Kim (2009) conducted research on 87 sworn officers and concluded that autonomy was statistically significant factor in job satisfaction. Ercikti et al. (2011) researched police managers and their job satisfaction and found that autonomy was positively related to job satisfaction. Adding to these studies, Johnson (2012) asserted that, with job autonomy, as ability of discretion increased, job satisfaction increased. Job 
autonomy, which is police discretion, seemed to show high significance in having positive job satisfaction for police officers. However, other indicators of work environment factors exist that influence job satisfaction.

\section{Job Stress}

Police officers, due to their unique work environment endure multiple types of job stress. Thus this job stress may lower officers' job satisfaction. Johnson asserted that higher levels of job related stress resulted in lower levels of job satisfaction (Johnson, 2012). Also, Zhao et al. (1999) stated that job stress and job satisfaction has negative relationship with one another. Job stress occurs when officers are strained in certain job tasks that they do not want. Hackman and Lawler found that job role strain or job stress occurs when employees do not want to carry out tasks they are required to do or feel they are not equipped to perform (Hackman \& Lawler, 1971). Other characteristics of work stressors have been noted in the past. For example, operational stressors, or job content stressors, would be stressors that might result in individual dissatisfaction of officers' jobs.

Other studies have shown that police officers have to deal with variety of unique occupational stress. Example of this type of stress might include the sudden death of a coworker, victim or suspect. Dealing with victims of crime, violence and accident may also be disturbing for law enforcement officers (Dietrich \& Smith, 1986). Also stressors related to court and the justice system as a whole, such as the courts failing to prosecute, tedious court appearances during busy schedules and workloads, and unpredictable work style and lifestyle can make planning of work and life impossible (Coman \& Evans, 
1998). As well, the perceived image of the public, including criticism and lack of status can also impact occupational stress for police officers (Lester, 1982). Not only are there mental stressors caused by the disturbing nature of the job, but there are also stressors caused by the organization of policing too. Hall (1986) identified several mid-career experiences that may cause considerable stress such as: perceived constriction of career opportunity, a slower growing or even declining organization, ambiguity and uncertainty about one's future career role, mid-career change experienced as disjunctive and individualized, greater awareness of changes in the work role, and lack of change (Hall, 1986). All laborers have job stress and it leads to job dissatisfaction, but due to the unique relationship of frontline supervisors and police officers, communication between these two must be examined.

\section{Job Feedback}

Feedback or any communication is vital among police officers. Bennett and Schmitt (2002) examined job dissatisfaction and cynicism in work environments. The authors highlighted variables that impacted police officers' job dissatisfaction. For example, when relations with supervisors are strained, police tend to be more cynical because they believe that their supervisors are not interested in their work or emotional state (Bennett \& Schmitt, 2002). Also, Miller et al. (2009) concluded that feedback was positively and significantly related with job satisfaction. Ercitki et al. (2011) also found that feedback had statistical significance on job satisfaction for police managers too. Good communication between the officer and supervisor is essential in job satisfaction. If there were no or bad communication among them, it could not lead to positive job 
satisfaction. On that note, job variety is important to explore due to unique occupational routine of police officers.

\section{Job Variety}

Police officers' occupational routine seems to influence officers' job satisfaction. In Johnson (2012), it has shown that job variety of police work was related to increases in job satisfaction. Zhao et al. (1999) supports this claim by suggesting that police officers' job satisfaction increases as the variety of work duties increase. Ercitki et al. (2011) discovered that police managers also found job variety to be important in their job satisfaction. Officers' job variety may influence officers' job satisfaction since they conduct the same routine everyday of their career. Even though various types of work environment seem to be a factor in police officers' job satisfaction, the current study puts most emphasis on the influence of frontline supervision and officer job satisfaction.

\section{Frontline Supervision \& Officer Job Satisfaction}

Officers have a unique relationship to frontline supervisors. This relationship can either make an officer satisfied or dissatisfied in his or her job. Supervisors play a critical role in directing and controlling subordinate officers' behavior (Walker, 2007). Although sergeants influence subordinate officers greatly, sergeants have not been researched in depth in policing (Walker, 2007). Even though demographics and work environment factors are crucial pieces of police officers' job satisfaction, due to immense influence of frontline supervision, sergeants are an essential piece to research. Thus it is indispensable to explore the frontline supervisor variable and its influence on subordinate officers' job satisfaction. Also, "Through their communication of higher levels strategies, sergeants 
should have an influence on officers' own attitudes toward the police role" (Ingram, 2013, p. 378). However, even though sergeants play a critical role in policing, sergeants have been not been the focal point of empirical research in policing. Walker (2007) came up with a critical question: Are certain styles of supervision associated with officers' job satisfaction?

\section{Role of Frontline Supervisors}

To see what influence frontline supervision actually has on job satisfaction, it is vital to explore prior literature that dealt with frontline supervision and job satisfaction. Supervisory style, at least in theory can influence subordinate officers both negatively or positively. First, the command model grounds the premise that sergeants will act with formal authority and direct and control subordinate officers' behavior by enforcing department regulations and requirements to perform in certain way (Allen \& Maxfield, 1983). Second, the exchange or bargaining model grounds the premises that both sergeant and subordinate officers are mutually dependent on one another (Van Maanen, 1983). That is, supervisors will ask the subordinate officers to cause no trouble and to perform abiding by the department regulation and in return, subordinate officers will ask for small favors such as better shifts, assignments, cars and protection from department discipline (Van Maanen, 1983). Sergeants dominate subordinate officers' actions and citizen encounters. This should be an important reason why frontline supervision should be researched. As illustrated above, there are various types of supervision that may reflect upon subordinate officers' job satisfaction. Supervisors hold an incredible amount of responsibility and influence over subordinate officers. As aforementioned, frontline supervision is vital in policing research; unfortunately, impact of frontline supervision 
has not been examined in depth. Also, frontline supervision's impact has not been examined in terms of the influence it has on police officer job satisfaction. For that reason, the following section explores research from other disciplines, officer perception of supervisors, and supervisory influences on other types of attitudes.

\section{Review of Research in Other Discipline}

As Madlock \& Kennedy-Lightsey (2010) suggest in their study, mentoring relationships of subordinates and supervisors may lead to both negative and positive outcomes. They also suggest that negative mentoring outcomes may result from verbal aggressiveness (Madlock \& Kennedy-Lightsey, 2010). For example, supervisors who are perceived by the subordinates as verbally aggressive are evaluated negatively compared to non-aggressive supervisor. With this assumption, Madlock \& Kennedy-Lightsey (2010) claim that supervisors have an important influence on the job and communication satisfaction of their subordinates.

Madlock \& Kennedy-Lightsey (2010) emphasize not only on job satisfaction of the supervisor and the subordinate relationship, but also focus on the communication satisfaction between the supervisor and the subordinate. From this, they suggest that communication appears to be a critical factor in the supervisor-subordinate relationship and subordinates' feeling about the job and the organization (Madlock \& KennedyLightsey, 2010). This study concludes that supervisors who had like characteristics with the subordinates showed more positive mentoring outcomes. For instance, strong negative relationships were determined between verbal aggression and subordinates' job satisfaction and a positive relationship was determined between supervisors' mentoring 
behaviors and subordinates' communication satisfaction (Madlock \& Kennedy-Lightsey, 2010). At the end, it was not mentoring or the attitude of the supervisor that brought down the job satisfaction. Indeed attitude played a partial role in job satisfaction but it was mentoring through communication satisfaction that had a more significant impact on job satisfaction (Madlock \& Kennedy-Lightsey, 2010).

\section{Officers' Perception of Supervisors and Job Satisfaction}

Supervisor support is one of the most important factors in police officer job satisfaction. As Griffin and her colleague suggest, the feeling of support by supervisors or colleagues, has consistently been link to job satisfaction outcomes (Griffin, Patterson, \& West, 2001). Such social support can be distinguished into three categories: support from supervisors, support from co-workers, and support from family/friends (Elias \& Mittal, 2011). In opposition, if an individual subordinate does not sense the support from their supervisor, job satisfaction may decrease (Elias \& Mittal, 2011). As this study concludes, employees with perception of support from their supervisors reported higher job satisfaction compared to their counterparts, and also had a more significant relationship of supervisor support and job involvement (Elias \& Mittal, 2011). Morris (1999) claims, that perception of the commanding officers support for officers in his/her command, including levels of fairness and favoritism that were under his/her control, would predict officers' organizational commitment and commitment to their profession. Additionally, supervisor may be the source of job satisfaction or dissatisfaction (Morris \& DuMont, 1999). 
Officers' perception of their supervisors' attitude may also have heavy influence on their job satisfaction. As Johnson (2012) concluded, even though supervisor feedback and organizational support did not show statistical significance, it was closely examined. Another research study conducted by Brehm and Gates (1994) provided evidence of how subordinates respond to supervisors' attitude according to allocation of tasks. This study concluded that supervision can be implemented however the supervisor wants but it is the subordinates' response that dictates the outcome of the job (Brehm \& Gates, 1994). From this, it may be possible to deduce that it depends on how the subordinate officers react to the perceived attitude of their supervisors that result in the outcome of subordinate officers' actions.

More literature about job satisfaction and police officer perceptions regarding supervisors exists. Patterson (1992) conducted research on the perception of police officers' job stress. Patterson (1992) concluded that personal support/technical support, ineffectiveness of work, political pressure within the department, and job schedule had statistical significance in police officers' perception in job stress. These factors of perception of job stress in Patterson's (1992) study may all be factors that are influenced by supervisors' attitude. For example, supervisors can impact how effective work is, how political pressure can be applied to subordinate officers according to supervisors' views of departmental discipline, and how supervisors may influence the perception of personal/technical support of individual officers. 


\section{Influence of Frontline Supervisors on Officers' Attitude}

Supervisors' characteristics or attitudes can actually impact how subordinate police officers act. Engel and Worden (2003) concluded that if the supervisor was male and had orientation toward aggressive enforcement, it significantly impacted the time subordinate officers spent on conducting problem solving activities and encounters. However, this study does conclude that supervisor attitude did not impact all of the subordinate officers equally. To explain, supervisor attitude did not have a direct impact on officers. For example, a supervisor can be well or less educated, but that was not a statistical determinant of subordinate officer attitude. From this, we may hypothesize that supervisor impact is not direct but rather may be relational. For example, an officer may or may not act in a certain way due to their supervisors' attitude, but at the end it all depends on the differences between an individual officer and their supervisor.

Frontline supervisors' attitudes are immensely important due to their conflicting role of responsibility towards their supervisor and responsibility towards their subordinate officers (Engel, 2000). Due to this, Engel (2000) suggested that supervisors may have major influence on subordinate officers' behavioral outcomes. Thus, since police officers' actions are an outcome of their attitude, frontline supervisors may greatly influence how subordinate patrol officers may behave (Engel, 2000). Therefore, Engel (2000) structured four different types of supervisory styles in police sergeants:

Traditional supervisors expect aggressive law enforcements from their subordinates and wants measurable outcomes (highly task oriented); Innovative supervisors expect more community oriented activities and are more open to innovation if it positively changes the organization; Supportive supervisors emphasize protecting their subordinate officers from 
departmental punishment and provide protection for officers; and Active supervisors partake field work and makes decisions to control subordinate officers out in the field. As Engel (2000) noted, there are various types of supervisor attitudes or styles that may influence subordinate officers' behavior.

Study conducted by Ingram (2013) displayed supervisory influence on subordinate officers' role ambiguity. This study provided that when supervisors and subordinate officers had incongruent views on order maintenance activities, role ambiguity was highest Ingram (2013). For example, when officers held emphasis on order maintenance but when supervisors did not, it resulted in high levels of role ambiguity (Ingram, 2013). From this study's results, it may be possible to deduce that different views of supervisors, or different styles of supervisors, may influence subordinate officers' job satisfaction. It is important to emphasize that it was not the top down impact of supervisor and subordinate officer; rather it was individual impact that occurred when the individual supervisor and subordinate officer views were incongruent. From this, we may reason that supervisor style may influence subordinate officers' behavioral outcomes according to subordinate officers' incongruence or congruency compared with the supervisor's style. Another study Johnson (2011) is worth mentioning due to its ironic results of supervisors' emphasis on traffic violation and the outcome of traffic citations given out by the subordinate patrol officers. Johnson (2011) found out when supervisors had high emphasis on traffic violation citation, subordinate patrol officers actually cited less traffic violations. This study also provided evidence of how supervisors' attitude may influence subordinate officers' attitudinal behavior. 


\section{Sergeants' Education and its Impact on Subordinate Officers' Behavior}

Prior research has provided conflicting findings about educational level of supervisor and its impact on subordinate officers' behavior. Engel (2001) examined supervisory styles and concluded that there was no statistically significance in regards to supervisors' educational level. In addition to Engel (2001), Engel and Worden (2003) also agreed that education was not a statistically significant factor when influencing subordinate officers' behavior or their behavior themselves. Contradicting to Engel (2001) and Engel and Worden (2003), Johnson (2011) found that supervisors with college degrees were more likely to direct subordinate officers with higher traffic citations. Furthermore, the more supervisor traffic citations the supervisors issue themselves, supervisors had more expectation of their subordinate officers to do the same (John son, 2011). However, the emphasis of supervisors (emphasis on traffic citations) was not greeted with subordinate officers. Johnson (2011) found that when the supervisors emphasized on traffic citations, the subordinate officers actually cited less.

\section{Limitations of Prior Research}

Although there have been numerous studies conducted on police officer job satisfaction, it is evident that multiple limitations exists in prior research. First, prior studies do not agree on univocal conclusions. For example, Buzawa (1984) had different findings for two police departments for the majority of the factors used in the study. Detroit and Oakland each had different statistical significance on variables such as: gender, education, marriage, and stress (Buzawa, 1984). Another example of incongruence in the research is illustrated by Zhao et al. (1999). In this study, the authors 
concluded that when looking at job satisfaction in terms of coworkers, only autonomy was shown to have statistical significance. On the other hand, in Carlan's (2007) research, many variables such as contribution, pay, autonomy, peer respect, job security, among other factors were shown to be significant predictors of job satisfaction. As evidence by the review of the literature above, researchers have yet to come to consistent conclusions on the topic. However, it is not only incongruence in findings that limits prior research.

When looking at the officers' education throughout prior research, educational level was gathered in many different ways. For example, Engel (2001) operationalized educational level as either a police officer having a four year college degree or not. For Carlan's (2007) research, educational level was coded in GED/high school, associates, bachelor, or master's degree and up. Also, various prior studies have different opinion on whether or not educational level actually has an impact on officers' job satisfaction level. For instance, Johnson (2012) and Zhao et al. (1999) found that educational level had influence on officers' job satisfaction level. Ercikti (2011) also agreed that educational level did not have an impact on officers' job satisfaction, but instead actually had an inverse relationship. In contrast, Buzawa (1984) concluded that educational level had a positive influence on job satisfaction.

Other important limitations exist on research conducted on educational obtainment and job satisfaction for police officers. For instance, Walker (2007) asserts, that even though police supervisors are a vital piece of police work, due to their close and unique relationship to subordinate police officers, policing research has neglected research on supervision. Also, even where supervisor research exists, it mainly looks at 
the broad concept of demographic characteristic differences of supervisor and the subordinate officer. It is hard to determine whether or not the variation of job satisfaction is due to demographic characteristics difference or work environmental differences. Also, these differences in job satisfaction are measured in general top down relation of supervisor and subordinate officer rather than looking at individual officer's difference compared to individual sergeant. 


\section{CHAPTER III}

\section{THEORETICAL FRAMEWORK}

\section{Overall Job Satisfaction and Edwin Locke}

The basis of the current thesis is overall job satisfaction of police officers. To examine overall job satisfaction, it is crucial to inspect Edwin Locke's (1976) theory of job satisfaction. Locke argued that job satisfaction results from discrepancy between perception (perception of reality of one's work) and expectation (expectation a person has towards his/her job). These perceptions can either be negative or positive. For example, winning the lottery may be a positive surprise that acts as positive outcome of job satisfaction; on the other hand being fired may be an example of negative surprise that leads to negative job satisfaction (Edwards, 2008). Locke's theory concluded with an equation of job satisfaction where satisfaction $(S)$ is equal to the discrepancy of value content $\left(\mathrm{V}_{\mathrm{c}}\right)$ and perceived amount $(\mathrm{P})$ multiplied by value importance $\left(\mathrm{V}_{\mathrm{i}}\right)$.

$$
\mathrm{S}=\left(\mathrm{V}_{\mathrm{c}}-\mathrm{P}\right) \mathrm{V}_{\mathrm{i}}
$$

To explain this, Edwards (2008) gives a very simple example of satisfaction of pay and temperature. When worker emphasizes high value importance in pay, their job satisfaction dramatically increases as pay rises. Similarly, when a worker has a mediocre

emphasis of value importance on pay, their job satisfaction still rises as pay rises. On the other hand, dealing with temperature, when the temperature is too low, satisfaction is 
low. As temperature increases, satisfaction increases until a worker's expectancy of temperature is exceeded. When their expectancy is exceeded, satisfaction decreases because it is too hot. As predicted, workers do not like being too hot at work but they do not mind getting paid more than what they should be getting paid. As aforementioned, Locke (1976) asserts four components of job satisfaction, expectancies, needs, values, and need-value conflicts. Thus, overall job satisfaction occurs when these four components are met. Using this theoretical framework, the current thesis aims to assert that job satisfaction or dissatisfaction occurs between the discrepancies of person to person's relational demography. To explain, job satisfaction or dissatisfaction occurs due to differences between the demographic characteristics of an individual officer and supervisor, in this case the discrepancy of educational level of supervisor and subordinate officer.

\section{What is Relational Demography?}

As relational demography is the core framework of the current thesis, it is important to explain what exactly relational demography is and how the concept developed through other research. Pfeffer (1985) brought the importance of demographic similarity in organizational behavior and explains that "Demography of an organization is nothing more than describing it in terms of the distribution on these various dimensions and that organizational demography is based on the data gathered on individuals, but is, in fact, a collective or unit-level property" (Pfeffer, 1985, p. 68). Pfeffer also emphasizes that "demographic factors are important in understanding and managing organizations because similarity is one of the most important bases of interpersonal attraction; and demographic features such as age, race, and sex both help to determine similarity and 
also signal that those who share these features are more likely to be similar" (Pfeffer, 1985, p. 69). Pfeffer also sheds light on the importance of demography by stating, "people who share experiences and attitudes are more likely to like each other because they will understand each other better and because liking someone who is similar is selfreinforcing as it ratifies one's own qualities" (Pfeffer, 1985, p. 69). Pfeffer (1985) concludes that it is the demography's effect on social relations and behavior, which makes demography important for understanding many things that occur in organizations. After Pfeffer's introduction to organizational demography, other scholars started to explore such phenomena.

First of all, the demographic similarity or dissimilarity among supervisorsubordinates may impact individuals' attitudes and behaviors, which also lead to individual outcomes (Perry, Kulik, \& Zhou, 1999). Also, inspecting discrepancies of demographic characteristics and relational demography, "treats demography as a social relationship between an individual and the group or another individual in the case of dyads" (Tsui, Porter, \& Egan, 2002, p. 900). Prior research explained relational demography, that similarity in demographics such as race and sex is often led to deeper similarity in attitudes, values, and beliefs. Thus, greater demographic similarity leads to stronger interpersonal relationship (Byrne, 1961). The basic premise is that, "greater similarity of values, beliefs, and experiences results in the reinforcing outcome of mutual validation" Avery et al. (2012, p. 84). Tsui and O'Reilly (1989) also concluded a similar explanation of relational demography, stating that similarity of an individual's demographic characteristics positively influences outcomes. Consequently, Avery et al. 
provides that "similarity between supervisors and subordinate officers... creates positive workplace relationships based on perceptions of liking and shared beliefs" (2012, p. 85).

Tsui et al. (2002) gives in-depth explanation of relational demography. Tsui et al. (2002) assumes the basic premise that "demographic similarities invoke an attraction dynamic whereby demographically similar individuals accentuate the positive attributes of each other and drive a positive social identity" (2002, p. 901). Deriving from this, it may be applied that officers (sergeants-subordinate officer) with similar demographic characteristics may treat each other favorably where job performance may have positive outcome. On the contrary, when there is dissimilarity among officers (sergeantsubordinate officer), they tend to treat and view each other less favorably where friction may occur and may lead to job dissatisfaction.

\section{How it May Apply to Current Thesis}

As previously reviewed, Herzberg (1959) asserts that supervision and leadership also is an essential part of job satisfaction. Thus, we may be able to link relational demography to this thesis. That is, when the characteristics of supervisor and subordinate officer do not get along, job dissatisfaction will follow. This is essentially what relational demography implies, that when there is discrepancy among individuals in terms of demographics, it may lead to dissatisfaction in the job. For example, Mehra, Kilduff, and Brass (1998) claimed that perceived similarity among individuals adopt interpersonal attraction and liking. To explain this phenomenon, Avery et al. (2012) stated that "perceived similarity is associated with a notion of shared historical experiences, values, and compatibility between interaction partners, which foster cohesion" Avery et al. 
(2012, p. 85). This may be applied to subordinate officers and sergeants. If subordinate officers and sergeants had similarity in terms of basic demographics, such as educational level, it may lead to more satisfaction. Simply put, a subordinate officer with a graduate degree will not get along with a sergeant with a high school diploma because of their educational differences.

The current thesis has three hypotheses responding to three research questions:

Research Question 1: Does officers' educational level impact their job satisfaction?

Hypothesis 1: The more educated the officer is, the officer will have less job satisfaction

Research Question 2: Does sergeants' educational level impacts their subordinate officers' job satisfaction?

Hypothesis 2: The more educated the sergeant is, subordinate officers will have less job satisfaction.

Research Question 3: Does the difference between officers' and sergeants' educational level impact officers' job satisfaction?

Hypothesis 3: The greater the discrepancy of educational level of sergeant and subordinate officer will lead to greater job dissatisfaction.

With these hypotheses in mind, the question becomes, how does relational demography apply to the current thesis, and how can relational demography explain why the current thesis has proposed these three hypotheses. 
The first hypothesis, "The more educated the officer is, the officer will have less job satisfaction", can be explained through prior research. As Locke states, "job satisfaction results from the perception that one's job fulfills or allows the fulfillment of one's important job values, providing and to the degree that those values are congruent with one's needs" (Lock, 1976, p. 1307). If this expectation of the job cannot be met, the subordinate officer will have dissatisfaction in his/her job. Another conflict of highly educated personnel is that, as Fabra Florit and Vila Lladosa (2007) concluded, if highly educated personnel do not and cannot get what they want that is expected in their job, dissatisfaction will be certain to occur. Furthermore, Regoli (1976) stated that better educated officers perceived themselves with more professionally qualified for the job but they were not allowed to have great amounts of autonomy due to regulations by the department. That is, when a subordinate officer with more education is not granted more autonomy, he/she may be dissatisfied with his/her job due to too much regulation or oppression by their less educated supervisor. To add to this, Trojanowicz and Nicholson (1976) also suggested that college educated officers preferred less regulation and control from their supervisors and wanted challenging jobs.

Like the first hypothesis, the second hypothesis holds similar reasoning, but oppositely so. To explain, sergeants who are also highly educated have certain expectations for their career, just as the subordinate officers, for that reason, will be dissatisfied if their expectations are not met. For example, Balci (2011) suggests that persons who are more educated expect more need for accomplishment and autonomy at work and more chances of advancement; when these desires are not met, an officer will become dissatisfied. 
As mentioned above through hypothesis I and II, prior studies have shown how inconsistent and limited the research was on these hypotheses. Therefore, the current study's hypothesis III looks at the relational effect of sergeant and subordinate officers' educational level difference. The third hypothesis: "Greater gap in the discrepancy of educational level between the sergeant and subordinate officer will lead to greater job dissatisfaction", can be explained through relational demography. When each subordinate officer and supervisor has a discrepancy in educational level, they will be more likely to not get along with one another. For example, Madlock and Kennedy-Lightsey (2010) study concluded that supervisors who had like characteristics with their subordinates showed more positive mentoring outcomes. The included strong negative relationships between verbal aggression and subordinates' job satisfaction, and positive relationship between supervisors' mentoring behaviors and subordinates' communication satisfaction (Madlock \& Kennedy-Lightsey, 2010). Therefore, when supervisors' style is congruent with subordinate officers' expectation of the supervisor, job dissatisfaction will occur. With that in mind, it would be safe to hypothesize that a supervisor and subordinate officer with similar or congruent relational demography, educational level specifically in this case, will be more likely to have higher job satisfaction on both sides.

Relational demography emphasizes that similar people will have less conflict and better relationship with one another. Most importantly, several studies show that having similarity in demographics with the supervisors is related to subordinate workers having more positive interactions and receiving more favorable treatment. On the other hand, dissimilarity with supervisors relate to less support, lower performance ratings, less attraction and greater role ambiguity (Foley, Linnehan, Greenhaus, \& Weer, 2006; 
Jeanquart-Barone, 1996; Tsui and O'Reilly, 1989). For that reason, relational demography is applied to this study by looking at the discrepancy of subordinate officers' characteristics and supervisors' characteristics to see the impact on job satisfaction. It is essential to observe the differences and similarities of police officers to examine job satisfaction regarding relational demography. Thus, the current thesis hypothesizes that discrepancies in demographic characteristics among supervisor-subordinate officers will impact level of job satisfaction of subordinate officers. Therefore, the current thesis aims to focus on the global job satisfaction of Locke (1976), as well as relational demography as the theoretical framework. The ultimate goal is to examine police officers' job satisfaction in regards to demographic characteristics and focus on educational level. 


\section{CHAPTER IV METHODOLOGY}

The main goal of this thesis was to answer three questions:

1. Does officers' educational level impact their job satisfaction?

2. Does sergeants' education level impacts their subordinate officers' job satisfaction?

3. Does the difference between officers' and sergeants' educational level impact officers' job satisfaction?

To examine the research questions above, it is essential to explain how the data were obtained, what the variables were, how the current thesis will be measuring each variable, and what the analytic strategy is.

\section{Data Source-Secondary Data}

The data for this research was obtained from the "Assessing Police Use of Force Policy \& Outcomes" project. The following section of sample \& data collection comes from a report submitted to the National Institute of Justice by Terrill, Paoline and Ingram (2011). This project had two phases of data collection. Phase I was initially carried out by administering mail surveys to a stratified random sample of police agencies across the country based on agency size and type. The purpose of Phase I was to distinguish 
whether or not an agency had a force continuum policy. This strategy resulted in 1,083 agencies. Before mailing the survey to all 1,083 agencies, 17 sworn officers from 14 different agencies were administered a pre-test of the survey. Three phases of mail surveys were conducted in order to raise the response rate and phone calls were made to every non-responding agency between the second and the third wave. At this point the response rate was $54.5 \%$, total of 591 responses. To increase the response rate, a final wave (fourth wave) was conducted for the remaining 492 respondents. As a result, an additional 72 responses were collected which totaled of 662 responses (61.1\%).

Due to practical limitations of examining all agencies surveyed in Phase I, in Phase II eight agencies were selected for further investigation. Agencies selected needed to meet several qualification criteria. First, agencies selected must have regular reporting of force via officer use of force reports. Second, agencies must have consistent use of force policies and reporting procedures. Third, agencies had to be medium to large in size. To see the difference among the selected departments, the project selected agencies that employed different policies for use of force: six agencies with linear design, one agency with matrix design, and one agency with wheel or circular design. Also, agencies selected were not too different among themselves in terms of: socio-economic status, race, unemployment, poverty, or crime rate. As a result of previously provided criteria for selection, 16 agencies were selected. Out of the total 16 agencies, eight agencies were selected for further exploration: Columbus, OH, Charlotte-Mecklenburg, NC, Portland, OR, Albuquerque, NM, Colorado Springs, CO., St. Petersburg, FL, Fort Wayne, IN, and Knoxville, TN. 
In sum, the agencies chosen in the study had to have internal validity, which is the overall degree of control exercised during the research. Thus, agencies had to be similar for measures, such as race compilation, unemployment rate, poverty rate, or crime rates. Although the agencies had to be similar, they also needed to be different for adequate variation, such as: differing policy types, jurisdiction size, and socio-economic status. For the data collection, the research team conducted multiple site visits over the course of two years at each agency. The data collection consisted of surveying patrol officers to assess their views on their department. Also, formal and informal interviews were conducted with officials at the middle and upper management levels.

\section{Description of Survey Methodology}

The survey questionnaire that was used on patrol officers contained 116 questions that aimed to measure officers' attitudes in regards to departmental policy, work environments, and background characteristics. After the survey was pre-tested on former and Florida and Michigan officers, it was administered to eight different departments that were chosen to be researched. The survey questions were administered to the officers during the roll call to capture all personnel and to be efficient, since officers are all gathered in one place during a roll call.

\section{Sample}

Out of this federally funded grant, which resulted in 765 patrol officers and 146 sergeants from eight different police departments, the present study took a sample of 601 patrol officers and 82 sergeants. From the eight original departments that were chosen in the NIJ funded Assessing Police Use of Force Policy and Outcomes study, this current 
study chose three departments for realistic comparability: Albuquerque, New Mexico (APD); Knoxville, Tennessee (KPD); and Fort Wayne, Indiana (FWPD). These three departments were chosen due to their similarity in departmental structure. For instance, they all had similar structures of assigning patrol officers to sergeants using a squad system. This similar structure of squads of officers makes it able for the current thesis to compare the three departments for differences among patrol officers' and sergeants' educational level that may have an influence on officer job satisfaction. 


\section{Measures}

Table 1. Description of Study Variables

\begin{tabular}{|c|c|}
\hline Variables & Description \\
\hline \multicolumn{2}{|l|}{ Dependent } \\
\hline Job & Additive index of three items: 1) I would not consider taking another job, 2) I \\
\hline Satisfaction & $\begin{array}{l}\text { like my job better than the average police officer does, and } 3 \text { ) I find real } \\
\text { enjoyment in my job. Three items were measured in a four point Likert scale: } \\
\text { one being agree strongly and four being disagree strongly }\end{array}$ \\
\hline \multicolumn{2}{|l|}{ Independent } \\
\hline Officer & Measured by: 1 8 ascending scale of level of education. $1=$ Less than high \\
\hline Education & $\begin{array}{l}\text { school. } 2=\text { High school diploma or GED. } 3=\text { Some junior college, but no } \\
\text { degree. } 4=\text { Associates degree. } 5=\text { More than two years of college, but no } \\
\text { degree. } 6=\text { Bachelor's degree. } 7=\text { Some graduate courses, but no degree. } 8= \\
\text { Graduate degree for patrol officers. }\end{array}$ \\
\hline Sergeant & Measured by: 1 8 ascending scale of level of education. $1=$ Less than High \\
\hline Education & $\begin{array}{l}\text { school. } 2=\text { High school diploma or GED. } 3=\text { Some junior college, but no } \\
\text { degree. } 4=\text { Associates degree. } 5=\text { More than two years of college, but no } \\
\text { degree. } 6=\text { Bachelor's degree. } 7=\text { Some graduate courses, but no degree. } 8= \\
\text { Graduate degree for Sergeants. }\end{array}$ \\
\hline officers > & Cases where officers had higher education levels than sergeants: $1=$ Yes, $0=$ \\
\hline Sergeant & No. \\
\hline officers $<$ & Cases where sergeants had higher education levels than officers: $1=$ Yes, $0=$ \\
\hline Sergeant & No. \\
\hline $\begin{array}{l}\text { officers }= \\
\text { Sergeant }\end{array}$ & $\begin{array}{l}\text { Cases where officers and sergeants had the same education levels: } 1=\text { Yes, } 0= \\
\text { No. }\end{array}$ \\
\hline \multicolumn{2}{|l|}{ Control } \\
\hline Officer Race & Measured by: White $=1$ and Non-White $=0$ \\
\hline Officer Tenure & $\begin{array}{l}\text { Officers' years of experience obtained by the roster provided by the } \\
\text { department }\end{array}$ \\
\hline Officer Gender & Measured by: female $=0$ and male $=1$ \\
\hline Supervisor & Measured by two items: Officers were asked if they believed that their \\
\hline Support & $\begin{array}{l}\text { supervisor looked out for their welfare and if their supervisor's approach was } \\
\text { discouraging }\end{array}$ \\
\hline Top & Measured by three questions to see if officers felt top management: treated \\
\hline Management & $\begin{array}{l}\text { officers fairly for minor rules violation, publicly recognized good } \\
\text { performance, and recognized contributions to team efforts }\end{array}$ \\
\hline Role & Measured by three survey questions: "I know exactly what is expected of me" \\
\hline Ambiguity & $\begin{array}{l}\text {,"I know what my responsibilities are", and "There are clear planned goals } \\
\text { and objectives for my job" }\end{array}$ \\
\hline Stress & $\begin{array}{l}\text { Measured by three items: "I am usually calm and at ease when I'm working", } \\
\text { "When I'm at work, I often feel tense and uptight", and "A lot of the time my } \\
\text { job makes me frustrated or angry" }\end{array}$ \\
\hline Cynicism & $\begin{array}{l}\text { Measured by two questions: whether or not officers had reason to be } \\
\text { distrustful of citizens and if officers have reason to be suspicious of citizens }\end{array}$ \\
\hline $\begin{array}{l}\text { Department } \\
\text { characteristics }\end{array}$ & $\begin{array}{l}\text { Department characteristics were give nominal level choices. } 0=\text { no and } 1= \\
\text { yes. Three departments: Albuquerque PD, Knoxville PD, and Fort Wayne } \\
\text { PD. }\end{array}$ \\
\hline
\end{tabular}




\section{Dependent Variable: Job Satisfaction}

It is important to clarify and explain how each variable was measured. For the dependent variable, job satisfaction, was measured by using a Likert scale of: 1) Agree Strongly, 2) Agree Somewhat, 3) Disagree Somewhat, 4) Disagree Strongly. For the purpose of interpretation of the Likert scale, the data will be re-coded for convenient result interpretation: one being "Disagree Strongly" and four being "Agree Strongly". The purpose of recoding the data is simple. When the data has no consistency in terms of Likert scale direction, it is confusing to understand. For that reason, the current data will be recoded. The survey questionnaire of job satisfaction was as follows:

1. "I would not consider taking another job"

2. "I like my job better than the average police officer does"

3. "I find real enjoyment in my job"

In order to combine three items into one additive index scale, it is essential to see the validity and the reliability of the survey questions first. To ensure the validity and the reliability, a factor analysis and a reliability test is required. Validity aims to see how accurately the survey questions measure the concept under consideration. Before using factor analysis, there are several prerequisites. First, the data in use must be interval level and normally distributed. Second, there should be no specification error in the model. Third, there should not be a small sample size (Walker \& Maddan, 2013). Reliability aims to see the consistency of the survey questions in hand. That is, if an officer 
answered three questions similarly or consistently, then that question would be reliable. In order to see if the questions are reliable, the current thesis intends to use reliability analysis. Usually, the Cronbach's Alpha measure should be 0.70. After factor analysis and reliability analysis have been used, we may see whether or not we can combine the three individual items.

To see how each officer responded to each job satisfaction item and to examine missing data, frequency tables reported in the Appendix was provided. The results show that there is little missing data with over 99 percent of officers' responding to each question. To check for reliability and validity of each category, reliability analysis and factor analysis was carried out for al attitudinal variables. Reliability analysis of job satisfaction shows how reliable each items were so that it would be appropriate to add them as an added index. Validity show how each item explains the dependent variable in question.

To see the reliability of job satisfaction, reliability analysis was conducted. Statistics concluded that the three items of job satisfaction had a reliability of $(\alpha=.606)$. Even though, it was stated above that the alpha level should be above .70, this thesis assumes that the reliability value of .61is sufficient for the job satisfaction measures. As Schmitt (1996) provides, the fewer the number of items available in the added index, the lower the alpha level is going to be. Since the job satisfaction measure has only three items in added index, it was decided that .61 was suitable to draw the cut off line. Finally, with the factor analysis, the validity of each of the items was examined. With the three items of job satisfaction variable, factor analysis provided that the Eigen value was 1.74, 
which is well above the proper cut off line of 1.00 . Therefore, the job satisfaction variable had acceptable validity and reliability measures to further conduct our study.

\section{Primary Independent Variable: Educational Level}

For the independent variables, the current thesis divided the educational variables in to three sections: 1) officer education level, 2) sergeant educational level, and 3) officer-sergeant educational difference variables. First, for officers' educational level, was measured by eight categories of educational level: 1) less than high school, 2) high school diploma or GED, 3) some junior college but did not earn degree, 4) associates degree, 5) more than two years of college but did not earn a bachelor's degree, 6) bachelor's degree, 7) some graduate courses but did not earn a graduate degree, and 8) graduate degree. Second, for sergeants' educational level, it was also measured by eight categories of educational level: 1) less than high school, 2) high school diploma or GED, 3) some junior college but did not earn degree, 4) associates degree, 5) more than two years of college but did not earn a bachelor's degree, 6) bachelor's degree, 7) some graduate courses but did not earn a graduate degree, and 8) graduate degree.

Finally, three educational difference variables were created. These variables were created as follows:

1) Patrol officers' educational level $>$ Supervisors' educational level

2) Supervisors' educational level $>$ Subordinate officers' educational level

3) Patrol officers' educational level = Supervisors' educational level

The following examples explain how the three different measures were coded. For example, if a subordinate officer had a graduate degree and the supervisor only had a 
high school degree, this would fall in case number one. Contrarily, if the supervisor had a graduate degree and the subordinate officer only had a high school degree, it would fall in case number two. Lastly, if both the supervisor and subordinate officer had the same level of education, then it would fall under case number three.

\section{Independent Variable: Basic Demographics}

Basic demographics were included for both officers and sergeants. In the current study these demographics included race, experience (tenure), and gender. The gender variable was coded female $=0$ or male $=1$. The Race variable was divided into two categories with: White $=1$ and Non-White $=0$. For the tenure variable, information was gathered from the departmental rosters that were provided by each department. Although basic demographics are independent variables, the current thesis includes basic demographics under control variables.

\section{Control Variables}

The control variables consisting of work environment factors were measured as: 1) Supervisor support, 2) Top management, 3) Role ambiguity, 4) Stress, and 5) Cynicism. The following section provides the items for each attitudinal variable and its reliability and validity analysis results. For 1) supervisor support variable, officers were asked if they believed that their supervisor looked out for their welfare and if their supervisor's approach was discouraging. The supervisor support variable had two items that had to be added into an index. To do that, reliability analysis and factor analysis was required. Statistics show that two items of supervisor support had reliability of $(\alpha=.68)$ which this thesis assumes to be appropriate for additive index. Also, for validity, factor 
analysis was conducted. Statistics show an Eigen value of 1.52, which is well above the suitable cut off line (1.00).

2) Top management was measured in three categories to see if officers felt top management: treated officers fairly for minor rules violation, publicly recognized good performance, and recognized contributions to team efforts. The three items for top management had to be converted into an added index. The reliability score revealed a $(\alpha=.79)$ and the validity score was 2.14 which are both well above the cutoff line.

3) Role ambiguity was measured by three survey questions: "I know exactly what is expected of me", "I know what my responsibilities are", and "There are clear planned goals and objectives for my job". The role ambiguity variable which is also a three item variable, needed to be converted into an added index. The reliability score was $(\alpha=.75)$ and validity score was 2.0 which both are well above the cutoff line.

4) Stress was measured through the following three dimensions: "I am usually calm and at ease when I'm working", "When I'm at work, I often feel tense and uptight", and "A lot of the time my job makes me frustrated or angry." The stress variable which also is a three item variable was added into a scale and tested for reliability and validity. Statistics show the reliability score of stress items was $(\alpha .=68)$ and the validity score was 1.84, which are both well over the cutoff line.

5) Cynicism was measured using two items consisting of: whether or not officers had reason to be distrustful of citizens and if officers have reason to be suspicious of citizens. The cynicism variable, which had to be converted into an added index, was 
tested for reliability and validity. Statistics provided that the reliability score for cynicism was $(\alpha=.78)$ and the validity score was 1.64 , which are both well over the cutoff line.

6) Departmental site variable was included as a control variable with the three departments (i.e. Albuquerque PD, Fort Wayne PD, and Knoxville PD). The site control variable was measured with a simple question asking if the responding officer belonged to a specific agency, by asking yes $=1$ and no $=0$. The site control variable was not used as an added index, thus no reliability analysis and validity analysis was required.

\section{Analysis}

As described in the measurement section, each variable was measured differently. For that reason, it is essential to apply different statistical tools for maximized results. Thus, the analysis for the present study is processed through three steps: 1) univariate analysis, 2) bivariate analysis, and 3) multivariate analysis. The first step, univariate analysis, is to examine the data to see if it is appropriate for regression analysis or if any basic assumptions were not met. Basic assumptions consist of: whether or not there is an outlier, the mean and standard deviation, and skewness and kurtosis of the data. These basic assumptions were examined for normal distribution. The second step was the analysis of bivariate correlation. The primary reason behind this statistical procedure was to examine how the variables influence one another and to see if there are any multicollinearity problems with the data. The third step was the regression analysis, which determined the strength and the direction of the relationship among variables.

Since the current study had more than one independent variable, regression allows the examination of the dependent variable and one or more independent variables. 
Regression will be used to see how certain dependent variable is altered when independent variables vary. OLS (Ordinary Least Square) is more preferable over binary or multinomial logistic regression (Kwak, Miguel, \& Carreon, 2012). The current study’s dependent variable was an additive scale, combining the three dependent variables of job satisfaction in to one dependent variable. Thus, we assume the additive scale is continuous which is the basic reasoning of using OLS regression application in this study. 


\section{CHAPTER V}

\section{RESULTS}

The results section will be divided into three parts: univariate analysis, bivariate analysis, and multivariate analysis. For univariate analysis, the goal is to describe what the data is and to see the overall composition of the data through descriptive statistics. Following the univariate statistics is bivariate statistics, where the goal is to see the correlation of variables. By implementing bivariate analysis, it can determine the direction of the relationship among dependent and independent variables. For example, bivariate analysis can tell whether or not the educational level of officers has a positive or negative relationship with job satisfaction. Also, in order to conduct multivariate analysis, certain prerequisite assumptions exist. In order to satisfy these prerequisite assumptions, univariate analysis needs to take place. Finally, the multivariate analysis provides the results of regression analysis. The results provide the strength and the direction of each variable's relation to officer job satisfaction. Thus, the following section below explains the results of univariate, bivariate, and multivariate analysis.

\section{Univariate Analysis.}

For descriptive statistics, the frequencies of each individual survey item are provided in the Appendix section. Here, the descriptive statistics of the index measure for the dependent variable, job satisfaction, needs to be explored. As provided in Table 2, the 
minimum value was three, the maximum value was 12 , the average score was 9.36 , and the standard deviation was 1.73 with a total response count of $n=593$. As the descriptive table 2 provides, the average score of 9.36 may be safe to be interpreted that, officer are somewhat satisfied with their jobs.

Next attention is turned to the independent variables, such as officers' education. For the general educational level of officers, responses show that the minimum value was two, maximum value was eight, and average level of education was 4.24 (between associates and more than two years of college but no degree). Also for sergeants' educational level variable, with 463 total response and 138 missing, the minimum value was two and maximum value was eight. With the average educational level of 5.32, it was safe to say that on average, sergeants had a bachelor's degree.

The three different levels of education were coded as 1) Police officers had a higher education compared to the sergeants, 2) sergeants had a higher education compared to the subordinate officers, and 3) both officers and sergeants had equal level of education. The descriptive statistics of case 1 illustrates that out of $n=455$ total responses, 114 police officers had a higher educational level compared to their sergeants. Descriptive statistics show that the minimum was zero, the maximum was 1 , the average score was .25 , and the standard deviation was .43 . In case 2 , there were 272 sergeants who had higher educational levels compared to the officers. The descriptive statistics showed: the minimum was zero, the maximum was one, the average score was .60 , and the standard deviation was .49. Finally, in case 3, there were 69 officers who had equal levels of education to their sergeant. The descriptive statistics show that the minimum was zero, the maximum was one, the mean was .15 , and the standard deviation was .36 . 
For the demographic variables, Table 2 shows that $75 \%$ of the officers were White. For officer gender, zero represented female and one represented male officers. The table 2 shows that $90 \%$ of respondents were male officers and $10 \%$ were female officers. For sergeants, Table 2 also shows that $82 \%$ of sergeants were White. For experience, the minimum experience was six years, the maximum was 48 and the average was 15.53 . For sergeant's gender, $90 \%$ were male and $10 \%$ were female supervisors.

For the control variables, which were all measured using additive index scales; descriptive statistics were also used to see the composition of the data. For supervisor support, the added index had $\mathrm{n}=597$ responses with a minimum value of two, maximum value of eight, average of 6.49 , and standard deviation of 1.44 , which may be safe to say that subordinate officers were generally satisfied with their supervisors' support. For the variable of top management, total response was $n=588$ with a minimum value of three, maximum value of twelve, average score of 6.54 , and standard deviation of 2.17 . With average score of 6.54, officers seemed to be neither satisfied nor dissatisfied with how the top management dealt business.

Continuing with the control variables, three survey items of role ambiguity was used as added index. The added index had $\mathrm{n}=593$ responses with a minimum value of three, maximum value of 12 , average score of 9.75 , and standard deviation of 1.67 , which may be safe to say that officers were clear what their job was in general. For stress variables, the added index had $n=595$ responses with a minimum value of three, maximum value of 12 , mean of 5.75 , and standard deviation of 1.76 . With stress variable's mean of 5.75, police officers were neither stressed nor comfortable at their job. For the police cynicism variable, the added index had 593 responses with a minimum 
value of two, maximum value of eight, average score of 5.16, and standard deviation of 1.50. The average score of 5.16 would represent slightly above the middle (value of 4 ) of police cynicism. For the three control variable department sites: Albuquerque PD, Fort Wayne PD, and Knoxville PD, data was gathered as yes (1) or no (0) responses.

Albuquerque had $n=301$ officers, Fort Wayne had $n=180$, and Knoxville had $n=120$ officers who responded. In Sum, the univariate analysis demonstrates that there are no outliers, problems of skewness or kurtosis that might create a problem in bivariate and multivariate analysis.

Table 2. Description of Study Variables

\begin{tabular}{|c|c|c|c|c|c|}
\hline \multirow[b]{2}{*}{ Job Satisfaction(3 items; $\alpha=.61$ ) } & \multirow[b]{2}{*}{593} & \multirow[b]{2}{*}{3.00} & \multirow[b]{2}{*}{12.00} & \multirow[b]{2}{*}{9.36} & \multirow{3}{*}{1.73} \\
\hline & & & & & \\
\hline \multicolumn{5}{|l|}{ Educational Variables } & \\
\hline Officer Education & 587 & 2.00 & 8.00 & 4.24 & 1.68 \\
\hline Sergeant Education & 80 & 2.00 & 8.00 & 5.32 & 1.74 \\
\hline Case 1 (Officer $>$ Sergeant) & 455 & 0.00 & 1.00 & 0.25 & 0.43 \\
\hline Case 2 (Officer $<$ Sergeant) & 455 & 0.00 & 1.00 & 0.60 & 0.49 \\
\hline Case 3 (Officer $=$ Sergeant) & 455 & 0.00 & 1.00 & 0.15 & 0.36 \\
\hline \multicolumn{6}{|l|}{ Officer Variables $(N=601)$} \\
\hline Male & 599 & 0.00 & 1.00 & 0.90 & 0.29 \\
\hline White & 596 & 0.00 & 1.00 & 0.75 & 0.43 \\
\hline Experience & 598 & 0.25 & 34.58 & 6.90 & 6.10 \\
\hline Supervisor Support (2 items; $\alpha=.68$ ) & 597 & 2.00 & 8.00 & 6.50 & 1.44 \\
\hline Top Management ( 3 items; $\alpha=.78$ ) & 588 & 3.00 & 12.00 & 6.54 & 2.17 \\
\hline Role Ambiguity (3 items; $\alpha=.74$ ) & 593 & 3.00 & 12.00 & 9.76 & 1.69 \\
\hline Stress ( 3 items; $\alpha=.68$ ) & 595 & 3.00 & 12.00 & 5.75 & 1.76 \\
\hline Cynicism ( 2 items; $\alpha=.78$ ) & 593 & 2.00 & 8.00 & 5.16 & 1.49 \\
\hline \multicolumn{6}{|l|}{ Department Control } \\
\hline Albuquerque PD & 601 & 0.00 & 1.00 & 0.50 & 0.50 \\
\hline Fort Wayne PD & 601 & 0.00 & 1.00 & 0.30 & 0.46 \\
\hline Knoxville PD & 601 & 0.00 & 1.00 & 0.20 & 0.40 \\
\hline \multicolumn{6}{|l|}{ Sergeant Variables $(N=82)$} \\
\hline Male & 82 & 0.00 & 1.00 & 0.90 & 0.29 \\
\hline White & 82 & 0.00 & 1.00 & 0.82 & 0.38 \\
\hline Experience & 82 & 6.00 & 48.00 & 15.53 & 7.52 \\
\hline
\end{tabular}




\section{Bivariate Analysis}

The purpose of bivariate analysis was to see the relationship among the variables. Correlation was conducted to examine the influence of each of the educational variables on job satisfaction: 1) educational level of officers and 2) educational level of sergeants, 3) Case 1 (officer $>$ sergeant), 4) Case 2 (officer $<$ sergeant), and 5) case 3 (officer $=$ sergeant). The goal was to see the statistical significance each primary independent variable had on job satisfaction. Table 3 provides statistical results of correlation among these educational variables and job satisfaction.

The educational level of officers was correlated to job satisfaction, but in a negative direction. Statistics show that $(\mathrm{r}=-.15, \mathrm{p}<.01)$ the educational level of police officer was actually negatively correlated with job satisfaction. That could be interpreted as, if an officer had more education, they had less job satisfaction. On the other hand, educational level of sergeants did not show any statistical significance with officer satisfaction ( $r=.09, \mathrm{p}>.05)$. Also, when officers had higher educational level than the sergeants, job satisfaction was negative with $(\mathrm{r}=-.15, \mathrm{p}<.01)$. This means that when the officer was more educated compared to the sergeant, officers had less job satisfaction. On the other hand, Case 2 (officers <Sergeant Education level) showed positive statistical significance with $(\mathrm{r}=.13, \mathrm{p}<.01)$. This suggests that when sergeants had a higher educational level compared to the officers, officers had more job satisfaction. For Case 3 (officers $=$ Sergeant Education level), the results were not statistically significant $(\mathrm{r}=.02$, $\mathrm{p}>.05)$. 
Table 3. Correlation of Educational Level Variables and Job Satisfaction

\begin{tabular}{lcccccc}
\hline Variable & 1 & 2 & 3 & 4 & 5 & 6 \\
\hline 1. Educational level of Officer & 1.00 & $\cdot$ & $\cdot$ & $\cdot$ &. &. \\
2. Educational level of Sergeant & -.04 & 1.00 &. &. &. &. \\
3. Case 1 (officer>Serg Edu level) & $.56^{* *}$ & $-.56^{* *}$ & 1.00 &. &. &. \\
4. Case 2 (officer <Serg Edu level) & $-.56^{* *}$ & $.63^{* *}$ & $.70^{* *}$ & 1.00 &. &. \\
5. Case 3 (officer =Serg Edu level) & $.09^{*}$ & $-.19^{* *}$ & $-.24^{* *}$ & $-.51^{* *}$ & 1.00 &. \\
6. Job Satisfaction & $-.15^{* *}$ & .09 & $-.15^{* *}$ & $.13^{* *}$ & .02 & 1.00 \\
\hline
\end{tabular}

**. $\mathrm{p}<.01$ level, *. $\mathrm{p}<0.05$ level (2-tailed)

To explore educational discrepancies among officers and sergeants further, analysis of variance (ANOVA) was used on the three different cases of education. ANOVA is an appropriate statistical test due to the interval level dependent variable (Job Satisfaction), nominal level independent variable (discrepancy of educational level between officers and sergeant), and the discrepancy of educational level being categorized into three group. ANOVA also served to identify whether there are any significant differences between the means of independent groups. We wanted to verify if the results were identical or different from the correlation analysis. The results show in table 4, in Case 1, when the officers had a higher level compared to the sergeants. When comparing Officer < Sergeant to Officer> Sergeant, there was a mean difference of -.611 $(\mathrm{p}<.01)$. For Case 2, when officers had a lower educational level than the sergeants, ANOVA concluded $\mathrm{p}=0.003(\mathrm{p}<.01)$. Lastly for Case 3 , when officers and the sergeants had equal levels of education, ANOVA showed $\mathrm{p}=0.140$, which did not have any statistical significance. From these results, we may make a case that when officers have more education than their sergeants, they are more satisfied with their job compared to when they have less education than their sergeants. 
Table 4. ANOVA Testing for Three Educational Cases

\begin{tabular}{llccc}
\hline Variable & & Mean Difference & Std. Error & Sig. \\
\hline Case 1 (Officer < Sergeant) & Officer>Sergeant & -.611 & .187 & $.003^{* *}$ \\
& Officer=Sergeant & -.486 & & \\
Case 2 (Officer > Sergeant) & Officer $<$ Sergeant & .611 & .187 & $.003^{* *}$ \\
& Officer=Sergeant & .125 & & \\
Case 3 (Officer = Sergeant) & Officer>Sergeant & .486 & .255 & .140 \\
& Officer $<$ Sergeant & -.125 & & \\
\hline
\end{tabular}

**. $\mathrm{p}<.01$ level, *. p < 0.05 level (2-tailed)

\section{Control Variables}

For independent variables with nominal level measures, such as: the race and gender of officers and sergeants, the Independent samples T-test was appropriate to conduct for several reasons. First, the dependent variable should be in a continuous scale. Because the dependent variable is job satisfaction, with interval level measurement, this assumption is met. Second, the independent variables should be categorical with two groups. The control variables of race and gender of officer and sergeant, fits this criteria due to its categorical measure. Thus, Independent T-test seems to be appropriate to conduct for our control variables. As Table 5 provides, for the officers' race variable, the independent T-test concluded that there was no variability between white and non-white officers $(p<.286)$. Also for the officers' gender variable, the independent T-test concluded that there were no statistical variability in terms of officers' gender and job satisfaction with its low $\mathrm{p}$ value, $\mathrm{p}=.116$. Similarly with officers' race variable, sergeants' race variable also did not show strong statistical significance, $p=.975$. Finally, sergeants' gender also was not a statistical factor, with $\mathrm{p}$ value of .196. The four control variables, after independent T-test proved to be non-significant. Since the significance levels could not be less or equal to .05 , which is the threshold. 
Table 5. Race and Gender T-test of Officers and Sergeants

\begin{tabular}{lcccc}
\hline & $\mathrm{F}$ & $\mathrm{T}$ & $\mathrm{df}$ & $\mathrm{Sig}$ \\
Officer Race & .392 & 1.069 & 586 & .286 \\
Officer Gender & .203 & -1.573 & 589 & .116 \\
Sergeant Race & 1.711 & .031 & 463 & .975 \\
Sergeant Gender & 1.439 & -1.296 & 463 & .196 \\
\hline
\end{tabular}

**. $\mathrm{p}<.01$ level, *. p < 0.05 level (2-tailed)

Due to interval level measures of numerous variables, correlation analysis was conducted to see the relationship among these variables and job satisfaction. As table 6 shows, officer experience variable was significantly correlated to job satisfaction ( $\mathrm{r}=-$ $.252, \mathrm{p}<.01)$ in a negative direction. This meant officers with more experience actually were less satisfied. Supervisor support was also highly correlated with job satisfaction $(\mathrm{r}=.284, \mathrm{p}<.01)$. This meant officers who felt more supervisor support had higher satisfaction. Top management variable also had significantly high correlation with job satisfaction $(\mathrm{r}=.201, \mathrm{p}<.01)$. This can be explained that officers who perceived top management was doing their job were generally more satisfied. Role ambiguity had high correlation with job satisfaction $(r=.350, \mathrm{p}<.01)$. This can be interpreted that, officers who were clear about what their role was as an officer, were more satisfied. The officer stress variable had high correlation with Job satisfaction $(r=-.318, p<.01)$. This negative correlation may mean that officers who felt more stress were generally not satisfied. Lastly, sergeants' experience was correlated with job satisfaction ( $\mathrm{r}=-.191, \mathrm{p}<.01)$. Sergeants' experience was negatively correlated to job satisfaction, which may suggest that officers who had more experience were generally less satisfied with their job. 
Table 6. Correlation of Control Variables and Job Satisfaction

\begin{tabular}{lcccccccc}
\hline Variable & 1 & 2 & 3 & 4 & 5 & 6 & 7 & 8 \\
\hline 1. Supervisor Support & 1 &. &. &. &. &. &. &. \\
2. Top Management & $.306^{* *}$ & 1 &. &. &. &. &. &. \\
3. Role Ambiguity & $.323^{* *}$ & $.404^{* *}$ & 1 &. &. &. &. &. \\
4. Stress & $.293^{* *}$ & $.152^{* *}$ & $.276^{* *}$ & 1 &. &. &. &. \\
5. Cynicism & .015 & $.082^{*}$ & .056 & $.155^{* *}$ & 1 &. &. &. \\
6. Officer Experience & $.204^{* *}$ & $.219^{* *}$ & $.135^{* *}$ & .044 & $.123^{* *}$ & 1 &. &. \\
7. Sergeant Experience & $.219^{* *}$ & $.333^{* *}$ & $.234^{* *}$ & .041 & -.088 & $.315^{* *}$ & 1 &. \\
8. Job Satisfaction & $.284^{* *}$ & $.201^{* *}$ & $.350^{* *}$ & $.318^{* *}$ & .044 & $.252^{* *}$ & $.191^{* *}$ & 1 \\
\hline
\end{tabular}

**. p <.01 level, *.p < 0.05 level (2-tailed)

For the three site variables, as shown in Table 7, ANOVA was conducted to see the variance among each department and added index of job satisfaction among officers. ANOVA of Albuquerque PD concluded $p=0.005$, which was statistically significant $(p$ $<.01)$. Also for Knoxville PD, the results showed statistical significance $\mathrm{p}=0.005$, $(\mathrm{p}<$ $.01)$. On the other hand, Fort Wayne PD showed no statistical significance with $\mathrm{p}=.468$. Thus, we may conclude that officers from Albuquerque were more satisfied with their job compared to Fort Wayne officers.

Table 7. ANOVA of Department Variables and Job Satisfaction

\begin{tabular}{lcccc}
\hline Variable & & Mean Difference & Std. Error & Sig. \\
\hline Albuquerque PD & Fort Wayne & .509 & .162 & $.005^{* *}$ \\
& Knoxville & .220 & & \\
Fort Wayne PD & Albuquerque & -.509 & .162 & $.005^{* *}$ \\
& Knoxville & -.288 & & \\
Knoxville PD & Albuquerque & -.220 & .187 & .468 \\
& Fort Wayne & .288 & & \\
\hline
\end{tabular}

**. $\mathrm{p}<.01$ level, *. $\mathrm{p}<0.05$ level (2-tailed) 


\section{Multivariate Analysis}

As foreshadowed previously in Chapter 4, the current thesis intends to employ multiple regressions for the multivariate analysis. Before conducting multiple regression analysis, a few assumptions have to be met. First, the dependent variable should be assumed as an interval or a ratio level variable. Since the dependent variable is an added index of job satisfaction, we assume the dependent variable to be an interval level measure. Second, for the multiple regression analysis to be carried out, two or more independent variables are needed. The current thesis has several independent variables, such as added index of supervisor support, top management, role ambiguity, stress, cynicism, and other demographic characteristics of both police officers and sergeants. The levels of measurement of independent variable can be continuous or categorical, which fits the current thesis. Since we have continuous level of independent variables such as the added index provided above and nominal level of independent variables such as: race, gender, experience, and department.

In order to see the predictors of our independent variables, the current thesis conducted two-diagnostic regression models. The difference of Model 1 and Model 2 was the educational variables included in the models. Model 1, included officer and sergeant education variables to answer research questions \#1 and \#2. In Model 2, the three different cases of educational difference among officers and sergeants were added in order to answer research question \#3.

In Model 1, we needed to first look at the adjusted $\mathrm{R}$ square value to see the explanatory power of our independent variables. As shown in table 8 , the adjusted $\mathrm{R}$ 
square value was .239. We may conclude that our independent variables combined explained $24 \%$ of our dependent variable, job satisfaction. Next, we specifically looked at each individual independent variable to see the effect that each independent variable had on job satisfaction. First, looking at the education level of patrol officer variable, with $p$ value of .004 and un-standardized coefficient $b$ value of -.134, it was clear that this independent variable had a negative effect on job satisfaction. We may interpret that one unit increase in the educational level of patrol officer, led to a -.134 unit decrease in job satisfaction. Thus concluding that as educational level of officers increased, their job satisfaction decreased.

Other independent variables had significant effects. Officer experience also had a negative effect on job satisfaction. With $\mathrm{p}$ value of .000 and $b$ value of -.058 , officers with more experience had less job satisfaction. This meant, as officers' experience increase by one unit, officers' job satisfaction decreased by -.058. With .000 significance level of the $\mathrm{p}$ value, it is safe to say that as officers gain more experience, their job satisfaction decreases. Also role ambiguity and stress also had significant negative effect on job satisfaction. Furthermore, stress variable had p value of .000 and un-standardized coefficient $b$ value of -.272 . This meant, when one unit increased in stress of officers, .272 unit decreased in job satisfaction. Meaning, the more stress officers felt on their job, the less job satisfaction they had. For role ambiguity variable the p value was .000 and $b$ value was .216. Due to the questioning of the survey item, one unit of increase in role ambiguity actually meant more clear understanding of officers' job. Therefore, when one unit of role ambiguity increased, job satisfaction level increased by .216. Meaning, officers with clear understanding of their job description had more job satisfaction. 
Lastly, for departmental control, Fort Wayne PD showed significance in $\mathrm{p}$ value with .040 and $b$ value of .486. This meant that Fort Wayne PD officers were more satisfied with their job compared to other two sites.

Table 8. Model 1 Regression

\begin{tabular}{lcccc}
\hline Variable & $\mathbf{B}$ & $\mathbf{S E}$ & $\mathbf{t}$ & $\mathbf{P}$ \\
\hline Educational Variables & & & & \\
Officer Education & -.134 & .046 & -2.928 & $.004^{* *}$ \\
Sergeant Education & .031 & .048 & .638 & .524 \\
Officer Variables & & & & \\
Gender & .399 & .252 & 1.582 & .114 \\
Race & -.034 & .178 & -.191 & .849 \\
Experience & -.058 & .013 & -4.603 & $.000^{* *}$ \\
Supervisor Support & .075 & .057 & 1.313 & .190 \\
Top Management & -.031 & .040 & -.778 & .437 \\
Role Ambiguity & .216 & .050 & 4.339 & $.000^{* *}$ \\
Stress & -.272 & .045 & -6.013 & $.000^{* *}$ \\
Cynicism & .095 & .051 & 1.844 & .066 \\
Department Control & & & & \\
Fort Wayne PD & .486 & .236 & 2.062 & $.040^{*}$ \\
Knoxville PD & .026 & .247 & .105 & .916 \\
Sergeant Variables & & & & \\
Gender & .221 & .245 & .904 & .367 \\
Race & .123 & .210 & .583 & .560 \\
Experience & -.021 & .014 & -1.509 & .132 \\
\hline **. p<01 level, * p<0.05 level (2-tailed) & & & \\
\hline
\end{tabular}

**. p <.01 level, *.p $<0.05$ level (2-tailed)

In Model 2, the goal was to answer research question \#3, whether or not the educational difference had any influence on job satisfaction. As mentioned above, in Model 2, the educational discrepancy case 1 and 2 are included. Before explaining the results of this model, an issue of multicollinearity needed to be addressed.

Multicollinearity increases the standard errors of the coefficients. These increased standard errors mean that coefficients for some independent variables may not be found statistically significant, when actually they are. In order to detect multicollinearity issues, 
tolerance levels and VIF levels were assessed. If the VIF level is around or greater than four, one of these variables must be removed from the regression model. With case 3 , the educational discrepancy variable included in the model, VIF values of case 1, case 2 and case 3 were 96.514, 115.443, and 64.712. As noted previously, VIF level greater than four alerts that there are multicollinearity issues. Therefore, the current thesis removed case 3 variable in order to reduce multicollinearity problems. As provided below in Table 9, no multicollinearity issues were found after removing case 3 variable. Furthermore, since the sergeant education level variable had no significance in Model 1, it was removed in Model 2 for better results.

Provided below in Table 9, are the results of Model 2 regression with multicollinearity diagnostics. For Model 2, the adjusted R squared was .238. The independent variables included in Model 2 explained 23.8\% of the variance in dependent variable. In terms of collinearity assessment, there were no variables with a VIF level above four. For the officer education variable, with $\mathrm{p}$ value of .052 and $b$ value of -.112 , every unit increase of officer education actually decreased the job satisfaction of officers by .112. Also, to answer research question \#3, we need to take a close look at Case 1 and Case 2 of the educational difference variable. As provided in Table 9 below, neither Case 1 nor Case 2 had any statistical significance. Case 1 had a p value of .423 and $b$ value of .197. Even though there was no statistical significance, it showed negative direction in relation to job satisfaction ( $b=-.197$ ). Also, Case 2 had $\mathrm{p}$ value of .893 and $b$ value of .029. Similarly with Case 1, Case 2 did not have any statistical significance in relation to job satisfaction. 
Experience also decreased job satisfaction by .058 for every unit increase in experience with $p$ value of .000 . Role ambiguity increased job satisfaction when officers were clearer about their role, with $\mathrm{p}$ value of .000 and $b$ value of .214 . Stress also had a negative effect on job satisfaction with $\mathrm{p}$ value of .000 and B value of -.217 . Whenever there was increase in officer stress, officers' job satisfaction decreased by .217. Fort Wayne officers had more job satisfaction with p value of .037 and $b$ value of .494 .

Table 9. Model 2 Regression

\begin{tabular}{lcccccc}
\hline Variable & B & SE & $\mathbf{t}$ & $\mathbf{P}$ & \multicolumn{2}{c}{ Collinearity } \\
\hline Educational Variables & & & & & Tolerance & VIF \\
Officer Education & -.112 & .058 & -1.947 & $.052^{*}$ & .563 & 1.775 \\
Case 1 (Officer > Sergeant) & -.197 & .246 & -.802 & .423 & .445 & 2.246 \\
Case 2 (Officer = Sergeant) & -.029 & .219 & -.134 & .893 & .437 & 2.290 \\
Officer Variables & & & & & & \\
Gender & .407 & .252 & 1.614 & .107 & .942 & 1.061 \\
Race & -.036 & .178 & -.201 & .841 & .864 & 1.157 \\
Experience & -.058 & .013 & -4.640 & $.000 * *$ & .822 & 1.217 \\
Supervisor Support & .075 & .057 & 1.313 & .190 & .768 & 1.301 \\
Top Management & -.029 & .040 & -.719 & .473 & .684 & 1.463 \\
Role Ambiguity & .214 & .050 & 4.299 & $.000 * *$ & .761 & 1.313 \\
Stress & -.217 & .045 & -5.971 & $.000 * *$ & .810 & 1.234 \\
Cynicism & .092 & .052 & 1.781 & .076 & .883 & 1.132 \\
Department Control & & & & & & \\
Fort Wayne PD & .494 & .236 & 2.092 & $.037 *$ & .388 & 2.574 \\
Knoxville PD & .002 & .240 & .007 & .995 & .674 & 1.484 \\
Sergeant Variables & & & & & & \\
Gender & .210 & .245 & .854 & .393 & .879 & 1.138 \\
Race & .126 & .210 & .599 & .550 & .828 & 1.207 \\
Experience & -.023 & .014 & -1.643 & .101 & .462 & 2.163 \\
\hline$* *$ p <.01 level, *.p $<0.05$ level $(2-t a i l e d)$ & & & & &
\end{tabular}




\section{CHAPTER VI}

\section{CONCLUSION}

The purpose of this thesis was to see the relationship of education and levels of job satisfaction when individual and work environment factors were incorporated. Due to the focus of prior research on either individual level characteristics or the work environment, it was essential for this thesis to incorporate the two and investigate the impact of education level on job satisfaction. Specifically, the current thesis asked three research questions.

1. Does officers' education level impact their job satisfaction?

2. Does sergeants' education levels impact their subordinate officers' job satisfaction?

3. Does the difference between officers' and sergeants' education level impact officers' job satisfaction?

To answer these research questions, relational demography was used as the theoretical framework. Also, in order to explore our research questions, 601 patrol officers and 82 sergeants were used from survey data collected and submitted to the National Institute of Justice by Terrill, Paoline and Ingram (2011), as part of the Assessing Police Use of Force Policy \& Outcomes project. With this data, this thesis used a three step analysis: 1) 
univariate analysis, 2) bivariate analysis, and 3) multivariate analysis to statistically explain the problem.

\section{Findings}

With the application of three step statistical procedure, the results were able to answer our three research questions. RQ1) what effect does officer education have on job satisfaction? To answer this question, it was essential to look back at our bivariate and regression results. As provided above, officers' education level was statistically significant in relation to job satisfaction, but in a negative direction. Officers' education level indeed had an effect on job satisfaction. When officers had higher education, they actually had lower job satisfaction. This finding supports prior research. As Regoli (1976) concluded that college educated officers were more cynical than less educated officers. Also, Lofkowitz (1974) found that higher educated officers with masters' degree were very negative towards their job.

Based on the bivariate and regression results, RQ2) was answered. RQ2) what effect does sergeant education have on job satisfaction? Statistically speaking, this thesis did not find any significance in sergeants' education level and job satisfaction. Prior research also had conflicting conclusions. Engel (2001) claimed that there was no statistical significance in sergeants' education level and job satisfaction. Engel and Worden (2003) also agreed that education was not a statistically significant factor when influencing subordinate officers' behavior. As such, the current thesis also did not find any significance in sergeants' education level and job satisfaction. 
Lastly, based on the findings, RQ3) was answered. RQ3) what effect does educational discrepancy between an officer and sergeant has on job satisfaction? During the bivariate analysis, it showed significant statistical relationship among three discrepancy levels of officer and sergeant education compared to job satisfaction. Case 1 showed significance towards job satisfaction with negative direction. Case 2 showed positive significance towards job satisfaction. Although these variables showed statistically significant relationship with job satisfaction, after controlling for various control variables, these became non-significant factors.

From the results provided by regression, we did not find any significance in the educational discrepancy of officer and sergeant in relation to job satisfaction was found. This result is conflicting with prior research. Madlock \& Kennedy-Lightsey (2010) concluded that supervisors who had like characteristics with subordinates showed more positive behavioral outcomes. Also, as Averty et al. (2012) concluded, perceived similarity among subordinates and supervisor is from similarity in experiences, values, and basic characteristics that encourage cohesion among the two. Tsui and O'Reilly (1989) concluded that similarity of an individuals' demographic characteristics positively influences outcomes. Although, previous literature review reviewed found that similarity or difference of education level among officers and sergeants should have a positive or negative pattern, this thesis did not show any pattern in educational level discrepancy and job satisfaction.

As emphasized throughout this thesis, the most important variable was the educational level of officers/sergeants and its effect on job satisfaction. Due to its importance, it is worthy of explaining which educational measures ended up being the 
most important factor for explaining officer job satisfaction. Out of five educational factors in this thesis: 1) educational level of officer, 2) educational level of sergeant, 3)

Case 1,4) Case 2, and 5) Case 3, bivariate analysis showed significance in three variables. Officers' education, Case 1, and Case 2 had significant impact on job satisfaction. Both education level of officer and Case 1 had a negative effect on job satisfaction and only case 2 had positive significance on job satisfaction. After controlling for other variables (Model 1 regression), only officer education had significant effect on job satisfaction. After controlling for more variables in Model 2 of regression, educational factors' effect on job satisfaction weakened. In the end, officer education was the only factor in educational level variables that actually had statistical significance on job satisfaction.

\section{Limitations}

With these implications in mind, certain limitations of the current study should be acknowledged. First, the limitation of generalizability is at question. Due to the fact that the survey data came from three departments participating in the National Institute of Justice funded project, Assessing Police Use of Force Policy and Outcomes, the current study may have limitations of generalizing the results to a broader context. The three departments the current study investigated were larger sized agencies, and so the results may not generalize to smaller agencies or metropolitan size large agencies. Smaller agencies may have different structure, such as tighter relationship between supervisors and subordinate officer, and supervisors having more direct control over subordinate officer due to this tight relationship. For that reason future research may be better if various sizes of departments as well as data from other countries were examined. 
Furthermore, the current study could not incorporate time component. Data this study used did not include a time dimension where the progress or decrease of job satisfaction could be measured according to increase of time. For example, an officer who spent six months or less may have trouble adjusting to the leadership style of their sergeant; therefore it may lead to job dissatisfaction. On the other hand, an officer who spent ten years with the same sergeant may report very high satisfaction rating because they have spent a decade together. Also, it is impossible to figure out when officers start to have satisfaction or dissatisfaction during their career because the data has no time component. If it was possible to calculate when officers' job satisfaction begins, it may be possible to avoid these types of dissatisfaction with time component study.

Lastly, measurement limitation of educational variable may exists. For example, the educational level discrepancy variable does allow this study to know if an officer has more or less education compared to sergeants. Unfortunately, the three discrepancy educational levels does not allow this study to know which officer has how much more education compare to each other. If the study allowed quantifying Educational discrepancy, it may be possible to know which officer with how much educational level fits which sergeants. In the future, studies could look into exact levels of educational difference between officer and sergeants to provide officers with a more favorable job environment for better job satisfaction.

\section{Practical Implications}

Based on the results, this thesis did find that officer education does have effect on job satisfaction of officers. For example, if subordinate officers have higher education, it 
lowered the job satisfaction. This is not suggesting departments hire less educated officers for better job satisfaction. However, it may be wise for agencies to recruit educated officers for challenging jobs. Officer with higher education levels but without challenging jobs tended to have less job satisfaction. For that reason, it would be reasonable for agencies to have educated officers who fit well with the structure of the department. Since every officer has different desires in each department, it is impossible to generalize what is the best for every officer and every agency throughout the United States.

Also, officers with more experience tended to dislike their job more. Officers with more stress are very much less satisfied with their job. Officers with clear role orientation have higher job satisfaction. Based on this statistical significance, this thesis may have a few practical implications. First, in order to increase job satisfaction of police officers, the departments need to reduce the level of stress the officers feel. Second, sergeants and the departments should have an unambiguous role orientation for police officers so that officers do not suffer role ambiguity which leads to job dissatisfaction. If these basic dissatisfactions can be changed, we may have less job turnover rates with police officers. When officers are dissatisfied with their jobs, it may lead to inefficient police work or even illegitimate actions by the police. When police officers leave due to their dissatisfaction, it is the burden of the state to recruit and train officers again which costs tax dollars. 


\section{Future Research}

Police officer job satisfaction has been one of the most studied topics in criminal justice research. It has been studied and researched in a variety of ways. Although police officer job satisfaction has been exploited, there still are several future directions that researchers may consider on the topic. First, as mentioned above, time dimension was a problem. Future research should strive to incorporate time dimension in to job satisfaction and see how officers and sergeants with different education or different characteristics relate to one another as time progresses. Future research should also look at how different types of educational discrepancy might add to our current understanding of the topic. Even though the current study used educational discrepancy as three categorized variables, future research should strive to specify the levels of educational

differences among officers and sergeants, and see how job satisfaction differs as the level of educational discrepancies differ. 


\section{REFERENCES}

Allen, D., \& Maxfield, M. (1983). Judging police performance: Views and behavior of patrol officers. In R. Bennett, Police at Work: Policy Issues and Analysis. Beverly Hills: Sage.

Avery, D., Volpone, S., McKay, P., King, E., \& Wilson, D. (2012). Is relational demography relative? How Employment status influences effects of supervisorsubordinate demographic similarity. Journal of Business Psychology, 27, 83-98.

Balci, F. (2011). The effects of education on police officer job satisfaction: The case of Turkish National Police . International Journal of Human Sciences, 8(2), 265285.

Bennett, R. R., \& Schmitt, E. L. (2002). The effect of work environment on levles of police cynicism: a comparative study. Police Quarterly, 5(4), 493-522.

Brehm, J., \& Gates, S. (1994). When supervision fails to induce compliance. Journal of Theoretical Politics, 6(3), 323-343.

Buzawa, A., Austin , T., \& Bannon, J. (1994). The role of selected socio-demographic and job specific variables in predicting patrol officer job satisfaction: A reexamination ten years later. American Journal of Police, 13(2), 51-75.

Buzawa, E. S. (1984). Determining Patrol Officer Job Satisfaction. Criminology, 22(1), 61-81.

Byrne, D. (1961). Interpersonal attraction and attitude similarity. The Journal of Abnormal and Social Psychology, 62, 713-715.

Carlan, P. (2007). The search for job satisfaction: A survey of Alabama policing. American Journal of Criminal Justice, 32, 74-86.

Coman, G., \& Evans, B. (1998). What police don't like about their job: Sources of dissatisfaction in police work. Australian police Journal, July, 116-117.

Dantzker, L. (1992). An Issue for police-educational level and job satisfaction. Journal of Police, 12, 101-118. 
Dantzker, M. L. (1994). Measuring job satisfaction in police departments and policy implications: An examination of a mid-size, southern police department. American Journal of Police, 12, 101-118.

Dietrich, J., \& Smith, J. (1986). The non-medical use of drugs including alcohol among police personnel: A critical literature review. Journal of Police Science and Administration, 14, 300-306.

Dowler, K. (2005). Job satisfaction, burnout, and perception of unfair treatment: the relationship between race and police work. Police Quarterly, 8(4), 476-489.

Edwards, J. (2008). Person-Environment Fit in Organizations: An assessment of theoretical progress. The Academy of Management Annals, 2(1), 167-230.

Elias, S. M., \& Mittal, R. (2011). The importance of supervisor support for a change initiative: An analysis of job satisfaction and involvement. International Journal of Organizational Analysis, 19(4), 305-316.

Engel, R. (2000). The effects of supervisory styels on patrol officer behavior. Police Quarterly, 3(3), 262-293.

Engel, R. (2001). Supervisory styles of patrol sergeants and lieutenants. Journal of Criminal Justice, 29, 341-355.

Ercikti, S., Vito, G., Walsh, W., \& Higgins, G. (2011). Major determinants of job satisfaction among police managers. The Southwest Journal of Criminal Justice, $8(1)$.

Fabra Florit, E., \& Vila Lladosa, L. (2007). Evaluation of the effects of education on job satisfaction: Independent single-equation vs. structrual equation models. International Atlantic Economic Society, 13, 157-170.

Foley, S., Linnehan, F., Greenhaus, J., \& Weer, C. (2006). The impact of gender similarity, racial similarity, and work culture on familty-supportive supervision. Group and Organization Management, 31, 420-441.

Griffin, M. A., Patterson, M. G., \& West, M. A. (2001). Job satisfaction and teamwork: the role of supervisor support. Journal of Organizational Behavior, 22, 537-550.

Haarr, N., \& Morash, M. (1999). Gender, race and strategies of coping with occupational stress in policing. Justice Quarterly, 16, 303-336.

Hackman, J., \& Lawler, E. (1971). Employee reactions to job characteristics. Journal of Applied Psychology, 55, 259-286. 
Hackman, R., \& Oldham, R. (1976). Development of the job diagnostic survey. Journal of Applied Psychology, 2, 159-170.

Hall, T. (1986). Breaking career routines: mid-career choice and identity development. San Francisco, California: Jossey-Bass.

Hassell, K. D., \& Brandi, S. G. (2009). An examination of the workplace experiences of police patrol officers: the role of race, sex, and sexual orientation. Police Quarterly, 12(4), 408-430.

Hertzberg, F., Mausner, B., \& Snyderman, B. (1959). The motivation to work. New York: Harper Brothers.

Herzberg, F. (1968). One more time: How do you motivate employees? Harvard Business Reviews, 46, 53-62.

Hunt, R., \& McCadden, K. (1985). A Survey of work attitudes of police officers: Commitment and satisfaction. Police Studies: International Review of Police Development, 17, 17-25.

Ingram, J. (2013). Supervisor-officer fit and role ambiguity. Policing: An International Journal of Police Strategies \& Management, 36(2), 375-398.

Jeanquart-Barone, S. (1996). Implications of racial diversity in the supervisor-subordinate relationship. Journal of Applied Social Psychology, 26, 935-944.

Johnson, R. (2011). Officer attitudes and management influence on police work productivity. American Journal of Criminal Justice, 36, 293-306.

Johnson, R. (2012). Police officer job satisfaction: A multidimensional analysis. Police Quarterly, 15(2), 157-176.

Kwak, D., Miguel, C., \& Carreon, D. (2012). Political legitimacy and public confidence in police: An analysis of attitudes toward Mexican police. Policing: An International Journal of Police Strategies \& Management, 35(1), 124-146.

Lester, D. (1982). Subjective stress and sources of stress for police officers. Psychological Reports, 50, 1094-1099.

Lock, E. (1976). The nature and causes of job satisfaction. In M. D. Dunnette, Handbook of industrial and organizational psychology (pp. 1297-1349). Chicago: Rand McNally. 
Locke, E. (1976). The nature and causes of job satisfaction. In M. D. Dunnette, Handbook of industrial and organizational psychology (pp. 1297-1349). Chicago: Rand McNally.

Lofkowitz, J. (1974). Job attitudes of police: Overall description and demographic correlates. Journal of Vocational Behavior, 5, 221-230.

Loo, R. (2004). A typology of burnout types among police managers. Policing, 27, 156165.

Madlock, P., \& Kennedy-Lightsey, C. (2010). The effects of supervisors' verbal aggressiveness and mentoring on their subordinates. Journal of Business Communication, 47(1), 42-62.

Mehra, A., Kilduff, M., \& Brass, J. (1998). At the margins: A distinctiveness approach to the social identity and social networks of under-represented groups. Academy of Management Journal, 41, 441-452.

Miller, H., Mire, S., \& Kim, B. (2009). Predictors of job satisfaction among police officers: Does personality matter? Journal of Criminal Justice, 37, 419-426.

Morris, A., \& DuMont, K. (1999). Contextual factors affecting the organizational commitment of diverse police officers: a level of analysis perspective. American Journal of Community Psychology, 27(1).

Oshagbemi, T. (1997). The influence of rank on the job satisfaction of organizational members. Journal of Managerial Psychology, 12(8), 511-519.

Patterson, B. (1992). Job experience and perceived job stress among police, correctional, and probational/parole officers. Criminal Justice and Behavior, 19(3), 260-285.

Perry, E., Kulik, C., \& Zhou, J. (1999). A closer look at the effects of subordinatesupervisor age differences. Journal of Organizational behavior, 20, 341-357.

Pfeffer, J. (1985). Organizational demography: Implications for management. California Management Review, 28(1), 67-81.

Regoli, R. M. (1976). The effects of college education on the maintenance of police cynicism. Journal of Police Science and Administration, 7(3), 340-345.

Stroshine, M. S., \& Brandi, S. G. (2011). Race, Gender, and Tokenism in policing: an emprical elaboration. Police Quarterly, 14(4), 344-365.

Terrill, W., Paoline, E., \& Ingram, J. (2011). Assessing Police Use of Force Policy and Outcomes. National Institute of Justice. 
Toch, H. (2002). Stress in policing. Washington DC: American Psychological Association.

Trojanowicz, R. C., \& Nicholson, T. G. (1976). A comparison of behavioral styles of college graduate police officer. Police Chief, 8, 56-69.

Tsui, A., Porter, L., \& Egan, T. (2002). When both similarities and dissimilarities matter: Extending the concept of relational demography. Human Relations, 55(8), 899929.

Van Maanen, J. (1983). The boss: First-line supervision in an American police agency. In M. Punch, Control in the Police Organization. Cambridge: MIT Press.

Walker, J., \& Maddan, S. (2013). Statistics in criminology and criminal justice. Burlington, MA: Jones \& Bartlett Learning.

Walker, S. (2007). Police accountability: current issues and research needs. Planning for the Future. Washington D.C.

Weiss, H. (2002). Deconstructing job satisfaction: Separating evaluations, beliefs, and affective experiences. Human Resources Management Review, 12, 173-194.

Zhao, J., Thurman, Q., \& He, N. (1999). Sources of job satisfaction among police officers: A test of demographic and work environment models. Justice Quarterly, 16(1), 153-172. 


\section{APPENDIX}

\section{TABLES}

Frequency Distributions of Job Satisfaction

\begin{tabular}{|c|c|c|}
\hline \multicolumn{3}{|c|}{ "I would not consider taking another job" } \\
\hline \multirow{3}{*}{$\begin{array}{l}\text { Disagree Strongly } \\
\text { Disagree Somewhat }\end{array}$} & Frequency & Percent \\
\hline & 41 & 6.8 \\
\hline & 125 & 20.8 \\
\hline Agree Somewhat & 194 & 32.3 \\
\hline Agree Strongly & 238 & 39.6 \\
\hline Missing & 3 & .5 \\
\hline Total & 601 & 100.0 \\
\hline \multicolumn{3}{|c|}{ "I like my job better than the average P.O. does" } \\
\hline Disagree Strongly & 17 & 2.8 \\
\hline Disagree Somewhat & 130 & 21.6 \\
\hline Agree Somewhat & 341 & 56.7 \\
\hline Agree Strongly & 108 & 18.0 \\
\hline Missing & 5 & .8 \\
\hline Total & 601 & 100.0 \\
\hline \multicolumn{3}{|l|}{ "I find real enjoyment in my job" } \\
\hline Disagree Strongly & 7 & 1.2 \\
\hline Disagree Somewhat & 27 & 4.5 \\
\hline Agree Somewhat & 282 & 46.9 \\
\hline Agree Strongly & 281 & 46.8 \\
\hline Missing & 4 & .7 \\
\hline Total & 601 & 100.0 \\
\hline \multicolumn{3}{|l|}{ Added Index of Job Satisfaction } \\
\hline 3.00 & 4 & .7 \\
\hline 4.00 & 2 & .3 \\
\hline 5.00 & 6 & 1.0 \\
\hline
\end{tabular}




\begin{tabular}{lcc}
6.00 & 22 & 3.7 \\
7.00 & 41 & 6.8 \\
8.00 & 95 & 15.8 \\
9.00 & 139 & 23.1 \\
10.00 & 116 & 19.3 \\
11.00 & 105 & 17.5 \\
12.00 & 63 & 10.5 \\
Missing & 8 & 1.3 \\
Total & 601 & 100.0 \\
\hline
\end{tabular}

Frequency Distributions of Supervisor Support

\begin{tabular}{|c|c|c|c|}
\hline \multicolumn{4}{|c|}{ "Supervisor looks out for personal welfare of subordinates" } \\
\hline & Frequency & Percent & \\
\hline Disagree Strongly & 26 & 4.3 & \\
\hline Disagree Somewhat & 51 & 8.5 & \\
\hline Agree Somewhat & 251 & 41.8 & \\
\hline Agree Strongly & 269 & 44.8 & \\
\hline Missing & 4 & .7 & \\
\hline Total & 601 & 100.0 & \\
\hline \multicolumn{4}{|c|}{ "Supervisor's approach discourages extra effort" } \\
\hline Disagree Strongly & 30 & 5.0 & \\
\hline Disagree Somewhat & 77 & 12.8 & \\
\hline Agree Somewhat & 221 & 36.8 & \\
\hline Agree Strongly & 270 & 44.9 & \\
\hline Missing & 3 & .5 & \\
\hline Total & 601 & 100.0 & \\
\hline \multicolumn{4}{|c|}{ Added Index of Job Satisfaction } \\
\hline 2.00 & 10 & & 1.7 \\
\hline 3.00 & 9 & & 1.5 \\
\hline 4.00 & 38 & & 6.3 \\
\hline 5.00 & 74 & & 12.3 \\
\hline 6.00 & 152 & & 25.3 \\
\hline 7.00 & 113 & & 18.8 \\
\hline 8.00 & 201 & & 33.4 \\
\hline Missing & 4 & & .7 \\
\hline Total & 601 & 100.0 & \\
\hline
\end{tabular}


Frequency Distributions of Top Management

\begin{tabular}{|c|c|c|}
\hline \multicolumn{3}{|c|}{ "Top management recognizes particularly good job" } \\
\hline & Frequency & Percent \\
\hline Disagree Strongly & 199 & 33.1 \\
\hline Disagree Somewhat & 224 & 37.3 \\
\hline Agree Somewhat & 145 & 24.1 \\
\hline Agree Strongly & 25 & 4.2 \\
\hline Missing & 8 & 1.3 \\
\hline Total & 601 & 100.0 \\
\hline \multicolumn{3}{|c|}{ "Top management treats fairly for minor violations" } \\
\hline Disagree Strongly & 104 & 17.3 \\
\hline Disagree Somewhat & 218 & 36.3 \\
\hline Agree Somewhat & 232 & 38.6 \\
\hline Agree Strongly & 39 & 6.5 \\
\hline Missing & 8 & 1.3 \\
\hline Total & 601 & 100.0 \\
\hline \multicolumn{3}{|c|}{ "Top management recognizes contributions to a team effort" } \\
\hline Disagree Strongly & 138 & 23.0 \\
\hline Disagree Somewhat & 232 & 38.6 \\
\hline Agree Somewhat & 193 & 32.1 \\
\hline Agree Strongly & 32 & 5.3 \\
\hline Missing & 6 & 1.0 \\
\hline Total & 601 & 100.0 \\
\hline \multicolumn{3}{|c|}{ Added Index of Top Management } \\
\hline 3.00 & 58 & 9.7 \\
\hline 4.00 & 59 & 9.8 \\
\hline 5.00 & 71 & 11.8 \\
\hline 6.00 & 114 & 19.0 \\
\hline 7.00 & 82 & 13.6 \\
\hline 8.00 & 82 & 13.6 \\
\hline 9.00 & 86 & 14.3 \\
\hline 10.00 & 14 & 2.3 \\
\hline 11.00 & 9 & 1.5 \\
\hline 12.00 & 13 & 2.2 \\
\hline Missing & 13 & 2.2 \\
\hline Total & 601 & 100.0 \\
\hline
\end{tabular}


Frequency Distributions of Role Ambiguity

\begin{tabular}{ccc}
\hline "There are clear, planned goals/objectives for my job" & \\
\hline & Frequency & Percent \\
Disagree Strongly & 23 & 3.8 \\
Disagree Somewhat & 81 & 13.5 \\
Agree Somewhat & 317 & 52.7 \\
Agree Strongly & 178 & 29.6 \\
Missing & 2 & .3 \\
Total & 601 & 100.0 \\
"I know what is exactly expected of me" & \\
\hline Disagree Strongly & 9 & 1.5 \\
Disagree Somewhat & 82 & 13.6 \\
Agree Somewhat & 311 & 51.7 \\
Agree Strongly & 193 & 32.1 \\
Missing & 6 & 1.0 \\
Total & 601 & 100.0 \\
"I know what my responsibilities are" & \\
\hline Disagree Strongly & 4 & .7 \\
Disagree Somewhat & 17 & 2.8 \\
Agree Somewhat & 243 & 40.4 \\
Agree Strongly & 334 & 55.6 \\
Missing & 3 & .5 \\
Total & 601 & 100.0 \\
Added Index of Top Management & & \\
\hline 3.00 & 4 & .7 \\
5.00 & 4 & .7 \\
6.00 & 16 & 2.7 \\
7.00 & 28 & 4.7 \\
8.00 & 63 & 10.5 \\
9.00 & 135 & 22.5 \\
10.00 & 136 & 22.6 \\
11.00 & 101 & 16.8 \\
12.00 & 601 & \\
Missing & & \\
Total & & \\
& 106.0 \\
\hline
\end{tabular}


Frequency Distributions of Job Stress

\begin{tabular}{|c|c|c|}
\hline & Frequency & Percent \\
\hline Agree Strongly & 264 & 43.9 \\
\hline Agree Somewhat & 293 & 48.8 \\
\hline Disagree Somewhat & 37 & 6.2 \\
\hline Disagree Strongly & 4 & .7 \\
\hline Missing & 3 & .5 \\
\hline Total & 601 & 100.0 \\
\hline \multicolumn{3}{|c|}{ "When I'm at work, I feel tense or uptight" } \\
\hline Disagree Strongly & 185 & 30.8 \\
\hline Disagree Somewhat & 272 & 45.3 \\
\hline Agree Somewhat & 122 & 20.3 \\
\hline Agree Strongly & 19 & 3.2 \\
\hline Missing & 3 & .5 \\
\hline Total & 601 & 100.0 \\
\hline \multicolumn{3}{|c|}{ "A lot of time my job makes me frustrated/angry" } \\
\hline Disagree Strongly & 121 & 20.1 \\
\hline Disagree Somewhat & 290 & 48.3 \\
\hline Agree Somewhat & 155 & 25.8 \\
\hline Agree Strongly & 32 & 5.3 \\
\hline Missing & 3 & .5 \\
\hline Total & 601 & 100.0 \\
\hline \multicolumn{3}{|c|}{ Added Index of Top Management } \\
\hline 3.00 & 70 & 11.6 \\
\hline 4.00 & 78 & 13.0 \\
\hline 5.00 & 110 & 18.3 \\
\hline 6.00 & 166 & 27.6 \\
\hline 7.00 & 74 & 12.3 \\
\hline 8.00 & 60 & 10.0 \\
\hline 9.00 & 20 & 3.3 \\
\hline 10.00 & 14 & 2.3 \\
\hline 11.00 & 1 & .2 \\
\hline 12.00 & 2 & .3 \\
\hline Missing & 6 & 1.0 \\
\hline Total & 601 & 100.0 \\
\hline
\end{tabular}


Frequency Distributions of Police Cynicism

\begin{tabular}{lcc}
\hline \multicolumn{3}{c}{ "Police officers have reason to be suspicious of most citizens" } \\
\hline Disagree Strongly & Frequency & Percent \\
Disagree Somewhat & 46 & 7.7 \\
Agree Somewhat & 199 & 33.1 \\
Agree Strongly & 265 & 44.1 \\
Missing & 87 & 14.5 \\
Total & 4 & .7 \\
"Supervisor's approach discourages extra effort" & 100.0 \\
\hline Disagree Strongly & 63 & \\
Disagree Somewhat & 234 & 10.5 \\
Agree Somewhat & 233 & 38.9 \\
Agree Strongly & 67 & 38.8 \\
Missing & 4 & 11.1 \\
Total & 601 & .7 \\
Added Index of Police Cynicism & & 100.0 \\
\hline 2.00 & 28 & \\
3.00 & 34 & 4.7 \\
4.00 & 167 & 5.7 \\
5.00 & 85 & 27.8 \\
6.00 & 185 & 14.1 \\
7.00 & 51 & 30.8 \\
8.00 & 43 & 8.5 \\
Missing & 8 & 7.2 \\
Total & 601 & 1.3 \\
\hline & & 100.0 \\
\hline
\end{tabular}

